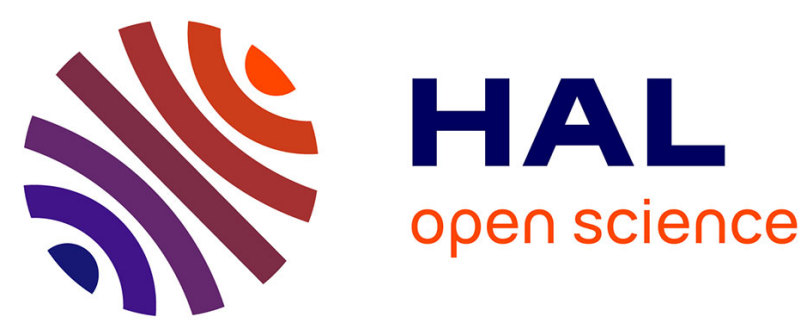

\title{
The apoptosis inhibitor Bcl-xL controls breast cancer cell migration through mitochondria-dependent reactive oxygen species production
}

\author{
Margaux Bessou, Jonathan Lopez, Rudy Gadet, Mathieu Deygas, Nikolay \\ Popgeorgiev, Delphine Poncet, Adrien Nougarède, Pauline Billard, Ivan \\ Mikaelian, Philippe Gonzalo, et al.
}

\section{To cite this version:}

Margaux Bessou, Jonathan Lopez, Rudy Gadet, Mathieu Deygas, Nikolay Popgeorgiev, et al.. The apoptosis inhibitor Bcl-xL controls breast cancer cell migration through mitochondria-dependent reactive oxygen species production. Oncogene, 2020, 39 (15), pp.3056-3074. 10.1038/s41388-020-1212-9 . hal-03094820

\section{HAL Id: hal-03094820 \\ https://hal.science/hal-03094820}

Submitted on 4 Jan 2021

HAL is a multi-disciplinary open access archive for the deposit and dissemination of scientific research documents, whether they are published or not. The documents may come from teaching and research institutions in France or abroad, or from public or private research centers.
L'archive ouverte pluridisciplinaire HAL, est destinée au dépôt et à la diffusion de documents scientifiques de niveau recherche, publiés ou non, émanant des établissements d'enseignement et de recherche français ou étrangers, des laboratoires publics ou privés. 
The apoptosis inhibitor $\mathrm{Bcl}-\mathrm{xL}$ controls breast cancer cell migration through mitochondriadependent Reactive Oxygen Species production

Margaux Bessou ${ }^{1}$, Jonathan Lopez ${ }^{1,2}$, Rudy Gadet ${ }^{1}$, Mathieu Deygas ${ }^{1 \#}$, Nikolay Popgeorgiev ${ }^{1}$, Delphine Poncet ${ }^{1,2}$, Adrien Nougarède ${ }^{1 @}$, Pauline Billard ${ }^{1}$, Ivan Mikaelian ${ }^{1}$, Philippe Gonzalo ${ }^{1,3}$, Ruth Rimokh ${ }^{1}$ * and Germain Gillet ${ }^{1,4} *$.

1. Université de Lyon, Université Claude Bernard Lyon 1, INSERM 1052, CNRS 5286, Centre Léon Bérard, Centre de recherche en cancérologie de Lyon, Lyon, 69008, France

2. Hospices civils de Lyon, Centre de Biologie Sud, Centre Hospitalier Lyon Sud, chemin du Grand Revoyet, 69495 Pierre Bénite, France

3. Laboratoire de Biochimie, CHU de Saint-Etienne, Université de Lyon, France

4. Hospices civils de Lyon, Laboratoire d'anatomie et cytologie pathologiques, Centre Hospitalier Lyon Sud, chemin du Grand Revoyet, 69495 Pierre Bénite, France

* these authors share senior authorship

\# present address: Institut Curie, CNRS UMR144, 6 rue Jean Calvin 75005 Paris, France.

@ present address: CEA LETI, 17 avenue des Martyrs, 38000 Grenoble, France

\section{Correspondence:}

germain.gillet@univ-lyon1.fr; Tel.: +33469166656; Fax: +33469166660

ruth.rimokh@inserm.fr; Tel.: +33478782903; Fax: +33469166660

\section{Running title:}

$\mathrm{Bcl}-\mathrm{xL}$ fosters migration of breast cancer cells 


\section{Abstract}

The $\mathrm{Bcl}-\mathrm{xL}$ apoptosis inhibitor plays a major role in vertebrate development. In addition to its effect on apoptosis, $\mathrm{Bcl}-\mathrm{xL}$ is also involved in cell migration and mitochondrial metabolism. These effects may favor the onset and dissemination of metastasis. However, the underlying molecular mechanisms remain to be fully understood. Here we focus on the control of cell migration by $\mathrm{Bcl}-\mathrm{xL}$ in the context of breast cancer cells. We show that $\mathrm{Bcl}-\mathrm{xL}$ silencing led to migration defects in $\mathrm{Hs} 578 \mathrm{~T}$ and MDA-MB231 cells. These defects were rescued by re-expressing mitochondria-addressed, but not endoplasmic reticulum-addressed, Bcl-xL. The use of BH3 mimetics, such as ABT-737 and WEHI539 confirmed that the effect of $\mathrm{Bcl}-\mathrm{xL}$ on migration did not depend on interactions with $\mathrm{BH} 3-$ containing death accelerators such as Bax or BH3-only proteins. In contrast, the use of a BH4 peptide that disrupts the $\mathrm{BCl}-\mathrm{xL} / \mathrm{VDAC} 1$ complex supports that $\mathrm{Bcl}-\mathrm{xL}$ by acting on VDAC1 permeability contributes to cell migration through the promotion of reactive oxygen species production by the electron transport chain. Collectively our data highlight the key role of $\mathrm{BCl}-\mathrm{xL}$ at the interface between cell metabolism, cell death, and cell migration, thus exposing the VDAC1/Bcl-xL interaction as a promising target for anti-tumour therapy in the context of metastatic breast cancer.

\section{Keywords:}

Bcl-x, breast cancer, migration, calcium, apoptosis, VDAC, mitochondria

\section{Introduction}

$\mathrm{Bcl}-\mathrm{xL}$ (also referred to as $\mathrm{BCL} 2 \mathrm{~L} 1$ ) is a key member of the $\mathrm{Bcl}-2$ family of apoptosis regulators(1). These proteins are involved in a complex network of interactions that control cell fate upstream of the mitochondria by keeping in check death-inducing factors, such as Cytochrome c(2).

In addition to the mitochondria pathway of apoptosis, some $\mathrm{Bcl}-2$ proteins were reported to have additional "non-canonical" roles (3). For instance, the death accelerator Bcl-wav was found to control the migration of blastomeres in the early steps of zebrafish development through $\mathrm{Ca}^{2+}$-dependent 
actin cytoskeleton remodeling, irrespective of apoptosis(4). Indeed, there is increasing evidence that $\mathrm{Bcl}-2$ proteins play a critical role regarding $\mathrm{Ca}^{2+}$ trafficking by interacting with several $\mathrm{Ca}^{2+}$ channels, including at the level of the endoplasmic reticulum $(5,6)$ and the mitochondria(7), a number of these interactions involving the $\mathrm{N}$-terminus $\mathrm{Bcl}-2$ homology domain referred to as $\mathrm{BH} 4$. Thus, in that way, $\mathrm{Bcl}-2$ proteins may be considered as multi-functional proteins acting, among others, on cell bioenergetics( 8 ) and $\mathrm{Ca}^{2+}$ homeostasis (9), beyond cell death.

$\mathrm{Bcl}-\mathrm{xL}$ is frequently overexpressed in cancers, including lung cancer(10), hepatocellular carcinoma(11) or breast cancer(12). Regarding breast cancer, Bcl-xL expression was correlated with enhanced metastatic potential rather than increased primary tumour growth $(13,14)$, Moreover, in breast tumours, Bcl-xL was recently reported to be specifically overexpressed at the level of the invasive boundary (15). Bcl-xL was also reported to contribute to metastasis dissemination in glioma(16) and pancreatic cancer(17).

In this work, we report that, contrary to $b c / 2, b c l x$ is over-expressed in breast tumours compared to normal tissue samples. We show that $b c l x$ silencing compromises the migration of Hs578T and MDAMB231 breast cancer cell lines, further supporting that $b c l x$ might contribute to metastasis dissemination. Mechanistically, we provide evidence that the Bcl-xL protein promotes cell migration by enhancing reactive oxygen species (ROS) production by the mitochondrial electron transport chain. Finally, our data support the notion that, during this process, $\mathrm{Bcl}-\mathrm{xL}$ prevents mitochondrial $\mathrm{Ca}^{2+}$ overload through VDAC1-BH4 interactions. 


\section{Results}

\section{Expression of $b c / x$, but not $b c / 2$, is of poor prognosis in breast cancers}

At the protein level, $\mathrm{Bcl}-\mathrm{xL}$ is accumulated in breast cancer cell lines with respect to the non tumourigenic breast epithelial MCF10A cell line, suggesting that its expression could be correlated to neoplastic transformation (Figure 1). To further ascertain the involvement of the bclx gene in breast cancer, we analysed $b c l x$ expression in breast tumours compared to normal samples using data from the TCGA databank. As previously reported(12), we found that $b c / x$ was overexpressed in breast tumours, unlike bcl2 (Figure 2A).

Next we assessed the expression of both genes within the breast tumour subtypes and found that $b c / x$ and $b c / 2$ were both overexpressed in oestrogen receptor-alpha positive breast tumours (Figure 2B, C). However, the clinical outcome associated with overexpression was different between the two genes. Indeed, high bc/2 expression was associated with better overall survival (OS) in TCGA and KM plotted cohorts (Figure 2B), whereas high bclx expression was associated with a reduced OS in both cohorts (Figure 2C). Regarding $b c / 2$ these results are consistent with previous findings linking bc/2 expression and good prognosis in breast cancer(18), thus validating the results obtained with both cohorts. Furthermore, tumors with invaded lymph nodes showed higher bclx expression levels, compared to non-invading samples whereas no difference was observed regarding bc/2 (Figure S1).

Together, these data highlight that $b c / x$ expression in breast cancer is associated with poor OS, unlike $b c / 2$, the expression of which is associated with good prognonosis. Therefore, we decided to focus on the role of the $\mathrm{Bcl}-\mathrm{xL}$ protein, in tumour progression by assessing its role on cell migration and invasion in the context of metastatic breast cancer.

\section{Impaired $b c / x$ expression leads to migration defects}

To achieve this goal, we used the highly invasive basal mammary cancer cell line Hs578T(19) as a model and performed siRNA-mediated knockdown (KD) of bclx. As shown in Figure 3A, siRNAs (referred to as siRNA 1 and 2) targeting the 3' UTR region of $b c / x$ mRNA efficiently reduced Bcl-xL 
protein levels. To limit interference from other $\mathrm{Bcl}-\mathrm{xL}$ functions such as apoptosis and proliferation(20), we measured the individual migration of $b c / x \mathrm{KD}$ cells by single cell tracking experiments. Bcl-x KD cells covered shorter distances $(295 \pm 20 \mu \mathrm{m}$ and $286 \pm 16 \mu \mathrm{m}$ for bclx siRNA treated cells vs $439 \pm 12 \mu \mathrm{m}$ for control cells, see Figure $3 \mathrm{~B}$ ) and displayed a reduced migration speed $(0,205 \pm 0,013 \mu \mathrm{m} / \mathrm{min}$ and $0,198 \pm 0,011 \mu \mathrm{m} / \mathrm{min}$ for $b c / x$ siRNA treated cells $v s$ 0,305 $\pm 0,009$ $\mu \mathrm{m} / \mathrm{min}$ for control cells, see Figure $3 \mathrm{C}$ ). We then performed a Boyden chamber assay, in which cells migrate towards increasing serum concentrations. Bclx KD cells consistently showed a reduced capacity to undergo directed migration in a serum gradient, the number of cells having crossed the membrane being $1.968 \pm 134$ and $1.656 \pm 106$ for $b c l x$ siRNA treated cells vs $2.459 \pm 105$ for controls cells (Figure 3D).

To further confirm these observations, we invalidated the $b c l x$ gene using the CRISPR/Cas 9 system(21) (Figure 3E). Indeed, Hs578T KO cells similarly exhibited slower migration, compared to the control cell line containing the empty vector (Figure 3F). In contrast, invalidation of $b c / 2$ did not affect cell migration to the same extent (Figure S2). To test whether the effect of $b c / x$ invalidation was cell type-dependent, we similarly invalidated $b c l x$ in another mammary cancer cell line (MDAMB231) which also exhibits high migration capacities. Indeed, as shown in Figure 3E-F, MDA-MB231 bclx KO cells showed a similar decrease in their migration capacities, compared to control MDAMB231 cells.

Finally, we evaluated the impact of $b c / x$ KO on Hs578T invasion properties in vivo, using a zebrafish xenograft model(22). Equal amounts of fluorescently-labelled Hs578T control and KO cells were co-injected into the yolk of $24 \mathrm{~h}$-old zebrafish embryos. Successfully injected embryos were subsequently incubated at $30^{\circ} \mathrm{C}$ for two days. At the end of the incubation time, the number of cell foci having escaped the injection site and invaded the tail were quantified (Figure 3G). Remarkably, the number of foci from control cells was more than $50 \%$ higher than bclx KO Hs578T cells (Figure $3 \mathrm{H})$. Hence, the zebrafish model confirmed that $b c / x$ KO cells display impaired cell motility and 
invasion in vivo. Altogether, these data highlight the involvement of $\mathrm{Bcl}-\mathrm{xL}$ in promoting the migration of human breast cancer cells.

To determine whether $\mathrm{Bcl}-\mathrm{X}$ expression affected metastasis formation, 4T1 control-shRNA or $b c / x-$ shRNA cells were injected into the tail veins of BALB/c mice, and their lungs were examined for metastases 21 days later. As shown in Figure 4A-B, the average number of visible metastatic nodules was markedly reduced in mice injected with Hs578T $b c / x$-shRNA cells relative to that of mice harboring 4T1 control-shRNA cells. Moreover, histological analyses confirmed that the number of micrometastatic lesions was reduced in the lungs of mice with 4T1 bclx-shRNA cells (Figure 4C). Thus the results from zebrafish and mouse models indicate that $\mathrm{Bcl}-\mathrm{xL}$ promotes both cell invasion and metastasis formation in vivo.

\section{The control of cell migration by $\mathrm{Bcl}-\mathrm{xL}$ is independent of its anti-apoptotic activity}

Next, we investigated whether the effect of $\mathrm{Bcl}-\mathrm{xL}$ on cell migration was related to its antiapoptotic activity. First, we noticed that $b c / x$ silencing using siRNAs induced minimal caspase activation as measured using a fluorescence emission-based assay $(1,15 \pm 0,24 \mathrm{AU}$ and $2,90 \pm 0,4 \mathrm{AU}$ for $b c l x$ siRNA treated cells vs $2.459 \pm 105$ for controls cells, see Figure 5A). However, as expected, $b c l x$ silencing strongly sensitized cells to staurosporine-induced cell death (Figure S3A). To definitely rule out that cell migration defects were related to cell death induction, we repeated the initial experiments in the presence of zVAD-fmk, a pan-caspase inhibitor (Figure S3A). Indeed bclx silenced cells displayed reduced migration capacities compared to control, even when caspase-dependent cell death was inhibited using zVAD-fmk (Figure 5B). As a control, we showed that zVAD-fmk treatment reduces staurosporine-induced cell death in Hs578T cells (Figure S3A). Together these results reveal that, the migration defects observed upon bclx silencing, were not linked to an activation of the caspases.

Then, we reasoned that if this assertion was true, the sole inhibition of the anti-apoptotic function of Bcl-xL should not impact cell migration. Indeed, the anti-apoptotic effect of Bcl-xL mainly relies on the binding of apoptosis accelerators, including $\mathrm{BH} 3$ only proteins, to the hydrophobic 
pocket of $\mathrm{Bcl}-\mathrm{xL}(1)$, this binding being efficiently targeted by $\mathrm{BH} 3$-mimetics(2). We thus treated Hs578T cells either with ABT737 or ABT263 (targeting both Bcl-xL and Bcl-2)(23) or with WEHI539 (targeting Bcl-xL only)(24), and measured migration at the single-cell level, as described above. Interestingly, no migration defect could be observed with either of these BH3-mimetics, compared to control cells treated with vehicle (Figures 5C-D). Importantly, we confirmed that all three strongly sensitized Hs578T cells to apoptosis in stressful conditions (Figure S3B). Therefore, the control of cell migration by $\mathrm{Bcl}-\mathrm{xL}$ does not appear to rely on interactions with pro-apoptotic $\mathrm{Bcl}-2$ family members at the level of its hydrophobic pocket.

\section{Mitochondria-targeted but not endoplasmic reticulum-targeted Bcl-xL rescues cell migration}

Bcl-xL has been reported to have different effects, depending on its subcellular localisation(25). In Hs578T cells, subcellular fractionation experiments showed that, although $\mathrm{Bcl}-\mathrm{xL}$ was mainly present in the mitochondrial compartment, a significant fraction of the protein was found in the microsomal fraction, containing the endoplasmic reticulum (ER), see Figure S4. To further investigate the relative contributions of both $\mathrm{Bcl}-\mathrm{xL}$ pools in cell migration, we designed plasmid constructs targeting Bcl-xL in either one of the compartments. To this end, we replaced the original $\mathrm{Bcl}-\mathrm{xL}$ transmembrane membrane (TM) domain with that of either the ActA (mitochondriaaddressed) or the Cytochrome B5 (ER-addressed) proteins, as previously described(26). Both chimeric $\mathrm{Bcl}-\mathrm{xL}$ proteins were localised subcellularly as expected, according to immunofluorescence staining (Figure 6A-B). For rescue experiments, we used the ProteoTuner inducible system (ClonTech). In this system, the protein of interest is fused to a destabilisation domain (DD) that targets the protein for proteasomal degradation in the absence of ligand(27). Conversely, in presence of the DD ligand (referred to as shield1), the protein accumulates. Indeed, as shown in Figure 6C, shield1 successfully induced the accumulation of Flag-tagged wild type (WT) Bcl-xL, as well as mitochondria- or ER-targeted $\mathrm{Bcl}-\mathrm{xL}$ in $\mathrm{Hs} 578 \mathrm{~T}$ KO cells. We then performed single-cell tracking experiments and demonstrated that WT Bcl-xL and mitochondria-addressed $\mathrm{Bcl}-\mathrm{xL}$ were both able to restore cell migration, while ER-targeted Bcl-xL, despite high expression levels, was unable to do so 
(Figure 6D). We also confirmed that mitochondria-targeted Bcl-xL was more efficient that ERtargeted Bcl-xL in promoting cell invasion in zebrafish (Figure 7). Together these results highlight that the mitochondrial pool of $\mathrm{Bcl}-\mathrm{xL}$, but not that of the $\mathrm{ER}$, is critical for controlling cell migration.

\section{Control of cell migration by Bcl-xL depends on its interaction with VDAC1}

As reported above, cell migration is not affected by $\mathrm{BH} 3$ mimetics, suggesting that the hydrophobic pocket of $\mathrm{Bcl}-\mathrm{xL}$ does not contribute to the control of cell migration by $\mathrm{Bcl}-\mathrm{xL}$, at least directly (Figure 5C-D). Besides interacting with the other Bcl-2 family members at the mitochondria, $\mathrm{Bcl}-\mathrm{xL}$ was reported to bind to the VDAC1 channel and hence regulate mitochondrial $\mathrm{Ca}^{2+}$ uptake $(7,8)$. We thus investigated whether VDAC1 could be involved in the observed effect of Bcl-xL on the migration of $\mathrm{Hs} 578 \mathrm{~T}$ breast cancer cells. It was previously demonstrated that the $\mathrm{BH} 4$ domain of $\mathrm{Bcl}-\mathrm{xL}$, located at the $\mathrm{N}$-terminus end outside the hydrophobic pocket, mediates $\mathrm{Bcl}-\mathrm{xL}$ interaction with $\operatorname{VDAC1}(28,29)$. Moreover, BH4-derived peptides were reported to disrupt the Bcl-xL/VDAC1 complex(30). Thus, to test whether the $\mathrm{BH} 4$ domain could contribute to the effect of $\mathrm{Bcl}-\mathrm{xL}$ on cell migration, we used a similar disrupting peptide based on the formerly described $\mathrm{Bcl}-\mathrm{xL} \mathrm{BH} 4$ sequence(28) (Figure 8A). This BH4 peptide was fused to an HIV-derived TAT sequence, to enable entry into the cells, and coupled to a TAMRA fluorophore, to allow tracking under the microscope (Figure 8B).

Single-cell tracking experiments were performed using Hs578T cells loaded with either TAT BH4 or negative control (TAT scr BH4). Contrary to cells loaded with TAT scr BH4, Hs578T cells loaded with the TAT BH4 disrupting peptide showed a reduced motility and speed of migration (Figure $8 \mathrm{C}$ ), mimicking the effect of $b c / x$ silencing. These results suggested that the TAT BH4 disrupting peptide inhibits cell migration by competing with endogenous Bcl-xL for VDAC1 binding. Furthermore, in a VDAC1-null context, cell migration was impaired irrespective of $b c l x$ expression, indicating that $\mathrm{Bcl}-\mathrm{xL}$ is unable to promote cell migration in the absence of VDAC1 (Figure S5). Collectively the above data support the idea that Bcl-xL acts on cell migration at the level of the mitochondria, by interacting with VDAC1 through its $\mathrm{BH} 4$ domain. 


\section{Bcl-xL fosters electron transport chain activity and mitochondrial ROS production}

Cytoskeleton remodeling is critical for cell migration(31,32) and closely depends on intracellular levels of ROS, which are mainly produced by the electron transport chain (ETC)(33-36). Importantly, Bcl-xL was reported to promote the activity of the ETC by acting at least partly on VDAC1 permeability and /or on the activity of the ETC complex $\mathrm{V}(8,37-39)$. These observations prompted us to investigate the consequences of $b c / x$ silencing on ETC activity and cellular ROS levels. First, using the fluorescent dye nonyl acridine orange (NANO) we found that $b c l x$ silencing did not affect the overall mitochondrial mass, suggesting that the number of mitochondria was unchanged (Figure S6). Still, bclx silencing resulted in a decrease in the oxygen consumption rate (OCR) and in the coupling efficiency (total basal OCR minus OCR value as measured after oligomycin addition), demontrating the contribution of $\mathrm{Bcl}-\mathrm{xL}$ in the regulation of oxidative metabolism and ETC activity in Hs578T breast cancer cells (Figure 9A-D). However ATP levels were not significantly affected (Figure 7E) whereas the OCR vs extracellular acidification ratio (OCR/ECAR) decreased by $32 \%$ (drop from 5.18 to $3.55, p=0.011$, see Figure 9D). In fact, glycolysis, which is already very active in native Hs578T cells, was further enhanced upon $b c / x \mathrm{KO}$, presumably allowing the cells to compensate for a decrease in mitochondrial ATP production (Figure 9F). Hence, these data show that impaired motility in $b c l x$ KO cells is not due to a drop in intracellular ATP levels and highlight the role of Bcl-xL as a promoter of oxidative metabolism and oxygen consumption by the ETC. It should be noted that $b c / x$ invalidation resulted in a similar decrease in ETC activity in MDA-MB231 cells, indicating that this effect is not restricted to a single breast cancer cell line (see supplementary Figure S7).

Mitochondrial ETC is the main contributor to production of ROS. The fact that the ETC appears to be slowed down upon bclx silencing, suggests that ROS production could also be affected, thus impacting cell motility. Indeed, the effect of $b c / x$ silencing on cell motility was replicated using the mitochondrial ROS scavenger MitoTempo (Figure 10A-B). Consistently, bclx silencing resulted in a decrease in overall ROS levels (Figure 10C) whereas mitochondrial ROS levels remained unchanged (Figure S8), indicating that the decrease in overall ROS levels is presumably due to a decline in 
mitochondrial ROS turnover impacting thus ROS output from the mitochondria. Of note, overall ROS levels were fully restored by overexpressing the mitochondria-addressed Bcl-xL protein (Figure 10D).

\section{Bclx silencing alters calcium trafficking in Hs578T cells.}

$\mathrm{Ca}^{2+}$ is known to directly contribute to many cell migration processes $(40,41)$. Moreover, the activity of the ETC is in part dependent on mitochondrial $\mathrm{Ca}^{2+}$ levels(42,43), suggesting that the observed alterations in oxidative metabolism and ROS production in $b c / x \mathrm{KO}$ cells could be linked to modifications in intracellular $\mathrm{Ca}^{2+}$ fluxes.

Since VDAC1 is a key player regarding mitochondria $\mathrm{Ca}^{2+}$ uptake, we investigated whether $\mathrm{Ca}^{2+}$ fluxes could be affected by $b c / x$ silencing or disrupting the Bcl-xL/VDAC1 complex. Following histamine treatment, which indirectly enhances mitochondrial $\mathrm{Ca}^{2+}$ uptake by promoting $\mathrm{ER} \mathrm{Ca}^{2+}$ release through the IP3R channels, we observed a significantly higher increase in mitochondrial $\mathrm{Ca}^{2+}$ levels in bclx KO Hs578T cells, compared to control cells (Figure $11 \mathrm{~A}-\mathrm{B}$ ). $\mathrm{Ca}^{2+}$ uptake increased similarly in isolated mitochondria from bclx KO cells, compared to controls (Figure 11C-D). Together, these data indicate that $b c / x$ silencing fosters mitochondrial $\mathrm{Ca}^{2+}$ uptake in $\mathrm{Hs578 \textrm {T }}$ breast cancer cells. We thus verified the effect of Bcl-xL/VDAC1 complex disruption on mitochondrial $\mathrm{Ca}^{2+}$ by cells loaded with the Bcl-xL TAT BH4 peptide, known to target and disrupt the Bcl-xL/VDAC1 complex(28). As shown in Figure 11E-F, the TAT BH4 peptide, but not theTATscrBH4 negative control, significantly increased mitochondrial $\mathrm{Ca}^{2+}$ uptake, following histamine treatment. Overall, these data suggest that $\mathrm{Bcl}-\mathrm{xL}$ may dampen mitochondrial $\mathrm{Ca}^{2+}$ uptake, presumably by acting on VDAC1 $\mathrm{Ca}^{2+}$ permeability. Furthermore, it should be noted that complementary experiments performed on whole cells revealed that cytosolic and $\mathrm{ER} \mathrm{Ca}^{2+}$ fluxes were also modified upon $b c / x$ silencing. In effect, ER $\mathrm{Ca}^{2+}$ release and subsequent cytosolic $\mathrm{Ca}^{2+}$ accumulation following histamine treatment were enhanced in $b c l x$ KO cells, compared to controls (Figure S9).

To further evaluate the contribution of VDAC1 permeability to cell migraton, we used the VDAC1 inhibitor DIDS, which is know to lower ETC activity and ROS production (44). Indeed, DIDS treatment 
mimicked the effet of $b c l x$ silencing regarding cell migration, whereas mitochondrial $\mathrm{Ca}^{2+}$ uptake was not significantly affected (Figure S10). Together these data suggest that the observed effect on migration following $b c l x$ invalidation mainly relies on ETC activity and subsequent decline in ROS production.

Finally, our data highlight a key role for mitochondrial Bcl-xL in controlling cell migration. They also suggest that this effect is correlated with modifications in ROS production and intracellular $\mathrm{Ca}^{2+}$ fluxes and depend at least in part on the formation of the Bcl-xL/VDAC1 complex. Collectively, our data support the notion that the observed cell migration impairment following $b c l x$ silencing is mainly due to changes in VDAC1 permeability, which subsequently impact ETC activity and ROS production. 


\section{Discussion}

In cancer cells, whereas the pro- and anti-apoptotic roles played by proteins belonging to the $\mathrm{Bcl}-2$ family have been extensively documented, emerging evidence suggests that $\mathrm{Bcl}-2$ proteins also affect the metabolic profile and the migration capacities of cells, which may impact the formation of metastases. Indeed, in a murine model of breast cancer, the Bcl-2 homolog $\mathrm{Bcl}-\mathrm{xL}$ was reported to favour metastases, independently of its anti-apoptotic effect(45). Moreover, the expression of $b c / x$ in breast cancer patients was of poor prognosis, unlike that of $b c / 2(13,14,18)$. Thus, depending on the context, the roles of $\mathrm{Bcl}-2$ family members may be different, or even antagonistic, which may impact their choice as therapeutic targets in a personalized medicine approach. For example, clinical trials testing $\mathrm{BH} 3$ mimetics targeting $\mathrm{Bcl}-\mathrm{xL}$ were prematurely interrupted due to their unexpected side effects on platelets(46). Hence, to minimize undesirable side effects, it is essential to draw a detailed picture of their mechanisms of action before developing strategies focusing on these proteins. Here, using the highly glycolytic Hs578T human cell line as a model of triple negative breast cancer, we investigated the contribution of the $\mathrm{Bcl}-\mathrm{xL}$ protein to cell migration and metastatic dissemination.

In mammals, $b c / x$ is ubiquitously expressed in embryos and adults(47). It is important during development, as illustrated by embryonic lethality in $b c l-x$ deficient mice(48). This lethality was correlated with massive apoptosis in the nervous system and neural tube closure defects. At the molecular level, Bcl-xL counteracts Bax death-inducing effects at the level of the mitochondria and maintains cytochrome $\mathrm{C}$ in check(49). In addition to its mitochondrial localisation, $\mathrm{Bcl}-\mathrm{xL}$ is also present in the nucleus and ER (reviewed by (50)). There is for example convincing evidence that Bcl$\mathrm{XL}$ interacts with the ER-resident IP3R $\mathrm{Ca}^{2+}$ channels and lowers IP3R $\mathrm{Ca}^{2+}$ permeability(51). On the other hand, $\mathrm{Bcl}-\mathrm{xL}$ was reported to lower $\mathrm{ER} \mathrm{Ca}{ }^{2+}$ levels by increasing $\mathrm{ER} \mathrm{Ca}^{2+}$ leak, thus preventing $\mathrm{Ca}^{2+}$ overload by stress-inducers and subsequent cell death (reviewed in(3)). Furthermore, it was suggested that $\mathrm{Bcl}-\mathrm{xL}$ may sustain mitochondrial metabolism by fostering mitochondrial $\mathrm{Ca}^{2+}$ uptake(6). The fact that, according to its localisation, $\mathrm{Bcl}-\mathrm{xL}$ appears to have distinct roles, was 
further confirmed by White and colleagues who reported that in mouse embryo fibroblasts, contrary to Mito-addressed $\mathrm{Bcl}-\mathrm{xL}$, ER-addressed $\mathrm{Bcl}-\mathrm{xL}$ is unable to prevent cell death induced by a number of agents, such as doxorubicin and staurosporine(25).

Here, using a loss of function approach, we report that, in the context of breast cancer, $\mathrm{BCl}-\mathrm{xL}$ is required for the optimal migration of HS578T cells. We show that, in steady-state conditions, $b c / x$ silencing compromises cell migration. Rescue experiments showed that mitochondria-addressed $\mathrm{Bcl}-$ $\mathrm{xL}$, but not ER-addressed $\mathrm{Bcl}-\mathrm{xL}$, partly restores these migration defects.

Mechanistically, we showed that this effect on cell migration was independent of (i) the mitochondrial apoptosis pathway, since $b c l-x$ silencing did not appear to affect caspase activity, and (ii) the ability of $\mathrm{Bcl}-\mathrm{xL}$ to bind and inhibit death accelerators with $\mathrm{BH} 3$ domains, such as $\mathrm{Bax}$ or $\mathrm{BH} 3$ only proteins, as $\mathrm{BH} 3$ mimetics, including the Bcl-xL-specific inhibitor WEHI-539, had no effect on cell migration. Of note, in a different context, $\mathrm{BH} 3$ mimetics targeting $\mathrm{Bcl}-\mathrm{xL}$ were in contrast reported to suppress the stimulating effect of CD95 on cell migration(52), suggesting that, in these latter conditions, the effects of $\mathrm{Bcl}-\mathrm{xL}$ on cell migration may be an indirect consequence of the inhibition of mitochondrial apoptosis.

Using a gain of function approach, Choi and colleagues recently reported also that Bcl-xL promoted cell migration and metastastic potential of pancreatic cancer cells, independently of Bax-dependent apoptosis(45). In this particular model, this effect might be the consequence of $\mathrm{Bcl}$-xL activity at the level of the nucleus, at least in part. It would thus be of interest to evaluate the contribution of Bcl$\mathrm{xL} / \mathrm{VDAC1}$ interactions to pancreatic cancer metastases.

Overall, our data highlight the role of the $\mathrm{Bcl}-\mathrm{xL}$ mitochondrial pool on cell migration. Furthermore, the use of the previously designed TAT-BH4-Bcl-x disrupting peptide, derived from the $\mathrm{BH} 4$ domain of $\mathrm{Bcl}-\mathrm{xL}$, which recapitulated the effects of $b c \mathrm{l}-\mathrm{x}$ silencing both on migration and mitochondrial $\mathrm{Ca}^{2+}$ uptake, suggests that these effects are VDAC1-dependent (see (28)). 
The actual effect of Bcl-xL on VDAC1 permeability is still a matter of debate. Initial studies using purified recombinant proteins claimed that Bcl-xL maintains a «closed» conformation of VDAC1 based on the measurement of sucrose uptake by liposomes(53). Structural and electrophysiological studies subsequently showed that VDAC1 is a barrel-shaped porin-like channel that allows ions $\left(\mathrm{Ca}^{2+}\right.$, $\mathrm{Na}^{+} \ldots$...), nucleotides (ATP, ADP...), certain metabolites (Creatine, Phospho-Creatine-...), as well as ROS, to cross the outer mitochondrial membrane. According to these studies, larger molecules such as cytochrome $\mathrm{C}$ are unable to cross the channel due to steric hindrance(54). Interestingly, electrophysiological measurements showed that the «closed» conformation of the channel (with low permeability for nucleotides and metabolites) exhibits, maximum $\mathrm{Ca}^{2+}$ permeability(55). However, in FL5.12 cells, during apoptosis induced by Interleukin-2 withdrawal, Vander Heiden and colleagues(37) observed a decrease in Creatine/Phospho-Creatine exchanges presumably due to VDAC1 conformational change. According to this model, such a conformational change would therefore allow massive entry of $\mathrm{Ca}^{2+}$ into the mitochondria, further promoting membrane permeability transition and swelling of the mitochondria, leading to the release of cytochrome $C$ and other pro-apoptotic factors.

Bcl-xL may thus maintain VDAC1 high permeability for metabolites in order to fuel the ETC, and at the same time prevent excessive mitochondrial $\mathrm{Ca}^{2+}$ uptake. Consistently, the TAT-BH4-Bcl-x peptide, known to disrupt the VDAC1/Bcl-xL interaction, increased mitochondrial $\mathrm{Ca}^{2+}$ uptake in MEFs(28). However, this model seems to contradict previous findings in permeabilized MEFs, in which invalidation of $b c l-x$ results in a decrease in mitochondrial $\mathrm{Ca}^{2+}$ uptake(7).

Thus in some instances Bcl-xL may promote mitochondrial uptake while in others it appears to have paradoxical effects. These apparent contradictions may be due to the use of different cellular models and $\mathrm{Ca}^{2+}$ flux measurement methods, they may also have some biological significance. Indeed depending on the context, $\mathrm{Bcl}-\mathrm{xL}$ may play opposite roles with regards to mitochondrial $\mathrm{Ca}^{2+}$ uptake, as described for $\mathrm{Bcl}-\mathrm{xL} / \mathrm{IP} 3 \mathrm{R} 1$ interactions(51). On the one hand, when the cellular priority is to support mitochondrial metabolism (ATP production via the ETC), Bcl-xL may contribute to 
maintaining the basal rate of $\mathrm{Ca}^{2+}$ uptake and the activity of Krebs cycle dehydrogenases that fuel the ETC. On the other hand, during $\mathrm{Ca}^{2+}$ stress, $\mathrm{Bcl}-\mathrm{xL}$ may prevent excessive $\mathrm{Ca}^{2+}$ entry into the mitochondria, thus avoiding metabolic dysfunction and subsequent cell death. According to this hypothesis, the metabolic profile of cells would determine the actual effect of $\mathrm{Bcl}-\mathrm{xL}$ (and possibly other $\mathrm{Bcl}-2$ homologs) on mitochondrial $\mathrm{Ca}^{2+}$ trafficking. In particular, in highly glycolytic contexts (embryonic cells, tumour cells) with low ATP production via the ETC, Bcl-xL may ensure basal ETC activity by maintaining metabolite shuttles between the mitochondrial matrix and the cytosol (including ADP/ADP and Creatine/Phospho-Creatine) and thus sufficient ROS production for cytoskeleton dynamics and cell movements(41). Accordingly, the decrease in ETC activity and ROS production after $b c l x$ silencing may be the consequence of VDAC1 conformational change, leading to both a drop in metabolite permeability and an increase in $\mathrm{Ca}^{2+}$ permeability, as we observed when monitoring isolated mitochondrial $\mathrm{Ca}^{2+}$ uptake in HS578T cells.

Finally, we also established that $b c l-x$ silencing impacts $\mathrm{ER} \mathrm{Ca}^{2+}$ trafficking, since $\mathrm{Ca}^{2+}$ release via IP3R channels increased in $b c / x$ KO cells following histamine treatment. Indeed, the effect of Bcl-xL on $\mathrm{ER} \mathrm{Ca}^{2+}$ release may indirectly affect the mitochondrial uptake of $\mathrm{Ca}^{2+}$ at the level of the ERmitochondria contact sites. An indirect contribution of the Bcl-xL reticular pool to cell migration, via the control of $\mathrm{ER} \mathrm{Ca}^{2+}$ fluxes, should therefore be considered. Interestingly, the zebrafish $\mathrm{Bcl}-2$ homolog Nrz was show to control migration in this way $(26,56)$. Regarding Bcl-xL, such a contribution can only be incidental, as the reticular $\mathrm{Bcl}-\mathrm{xL}$ protein alone is unable to restore normal migration of $b c / x$ KO cells. Collectively our data highlight the key role of $\mathrm{Bcl}-\mathrm{xL}$ at the interface between cell metabolism, cell death and cell migration, thus exposing the VDAC1/Bcl-xL interaction as a promising target for anti-tumour therapy in the context of metastatic breast cancer. 


\section{Materials and Methods}

\section{Cell culture and antibodies}

The 4T1 mouse adenocarcinoma cell line was from ATCC (ref CRL-2539).

Regarding human cell lines, Cal51 and MDA-MB468 were from DSMZ GmbH, whereas HS578T, MCF10A, T47D, MCF-7, CAMA-1, MDA-MB231 and MDA-MB157 were from ATCC. All human cell

lines (including $b c / x$ KO cells) were authenticated by single nucleotide polymorphism profiling (Multiplexion $\mathrm{GmbH}$ ). Cell lines were routinely tested for mycoplasma contamination using Mycoalert kit (Lonza).

Hs578T and MDA-MB231 human mammary cancer cell lines were cultured in DMEM Glutamax (Gibco) supplemented with $10 \%$ fetal bovine serum and $1 \%$ penicillin/streptomycin, at $37^{\circ} \mathrm{C}$ under a $5 \% \mathrm{CO}_{2}$ damp atmosphere.

The following antibodies were used: Bcl-xL (B22630-050, BD), Tubulin (SC-32293, Santa Cruz), Vinculin (SC-55465, Santa Cruz), mouse Flag (F3165, Sigma), rabbit Flag (F7425, Sigma), Calnexin (2679, Cell Signaling), FOF1 ATPase (612518, BD Biosciences), and Bcl-2 (Ab194583, Abcam).

\section{Plasmid DNA constructs}

For the CRISPR/Cas9-induced Bcl-xL knockout (KO), single guide RNA targeting Bcl-xL was designed using the MIT CRISPR design tool (http://crispr.mit.edu/). The following guide sequences (5'-CACCGGCAGACAGCCCCGCGGTGAA-3') and (5'-GAGAACAGGGTACGATAACCGGG-3') for bclx and $b c / 2$ respectively were cloned in the plentiCRISPRV2 vector(21). Hs578T and MD-MBA231 KO cell lines were generated upon infection with recombinant lentivirus particle containing plentiCRISPRV2_bclx or plentiCRISPRV2_bcl2 guide. Empty vectors served as controls. Cells were selected using $1 \mu \mathrm{g} / \mathrm{mL}$ puromycin.

For rescue experiments, pMX DD Flag Bcl-xL vectors were designed, either containing full length human $\mathrm{Bcl}-\mathrm{xL}$ sequence (Bcl-xL WT), $\mathrm{Bcl}-\mathrm{xL}$ fused to ActA or Cytochrome $\mathrm{B} 5$ transmembrane domain. All constructs contain silent mutations in order to be insensitive to Cas9-mediated Bcl-xL KO. 
Hs578T Bcl-xL KO cell lines were stably infected with pMX DD Bcl-xL constructs and selected using $1 \mu \mathrm{g} / \mathrm{mL}$ puromycin and $5 \mu \mathrm{g} / \mathrm{mL}$ blasticidin, concomitantly. Expression of the constructs was assessed by Western blot, following an overnight treatment with $0.1 \mu \mathrm{M}$ DD ligand shield1 (Clontech).

siRNA and transfection

SiRNA1 (5'-ACCAGGAGAACCACTACATGCAGCC-3') GTTCCAGCTCTTTGAAATAGTCTGT-3') both targeting Bcl-xL were purchased from IDT (Coralville, USA). Scrambled siRNA (AllStars negative control) was obtained from Qiagen. Forty eight hours before experiments, siRNA were transfected at a final concentration of $5 \mathrm{nM}$ using lipofectamine RNAimax reagent (Life technologies), according to the manufacturer's instructions.

\section{Single cell tracking experiments}

Twenty four hours prior to performing the experiment, cells were seeded onto a 24-well Essen image lock plate (Essen Bioscience). Before incubation in the Incucyte Zoom device, the culture medium was replaced by fresh medium containing additional reagents when appropriate. Cells were scanned every $30 \mathrm{~min}$. for $24 \mathrm{~h}$, providing 2 images per well per scan. In some instances the cells were

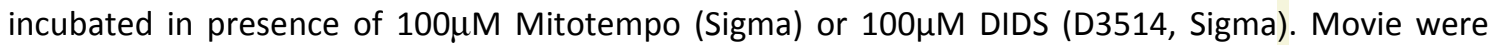
generated using the Incucyte software whereas cells were individually hand-tracked with ImageJ using a in-house plugin. 


\section{Boyden chamber assay}

Cells were grown overnight in 1\% FBS medium. The next day, 12,500 cells per well were seeded in a serum-free media on the top compartment of a 96 -well $8 \mu \mathrm{m}$ pore Fluoroblock plate (BD Biosciences). $200 \mu \mathrm{L}$ of $10 \%$ FBS medium was added in the bottom compartment of the plate. Each condition was performed in duplicate. Plates were subsequently incubated for $7 \mathrm{~h}$ and $30 \mathrm{~min}$. At the end of incubation time, medium of the lower compartment was replaced by a calcein-containing medium for $20 \mathrm{~min}$. Fluorescent cells at the bottom of the membrane were pictured using an inverted microscope. The number of cells on each picture was counted with an in-house ImageJ plugin.

\section{Zebrafish invasion assay}

Zebrafish (crosses between $A B$ and TU strains) were raised according to standard procedures. Hs578T empty or Bcl-xL KO cell lines were trypsinised from a confluent petri dish. Cells were centrifuged and subsequently washed three times with PBS. Cells were then diluted in PBS to a final concentration of 1 million cells per $\mathrm{mL}$. Next, $500 \mu \mathrm{L}$ of each cellular suspension were incubated at $37^{\circ} \mathrm{C}$ with $1 \mu \mathrm{L}$ of either Dil (red) or DiO (green) Vybrant dye (Thermofisher Scientific) for $30 \mathrm{~min}$. Cells were regularly mixed during incubation to favor complete labelling of the cell suspension. Labelled cells were finally washed three times with PBS and red and green cell suspensions were pooled during the second washing step. Cells were resuspended to a final volume of $50 \mu \mathrm{L}$ in culture medium. 24 h-old dechorionated zebrafish embryos were microinjected into the yolk with the freshly prepared cell suspension. Tricaine (Sigma) was used to anaesthetize embryos during the injection. Successful microinjection was visualised under a fluorescent microscope. Injected zebrafish embryos were incubated for two days at $30^{\circ} \mathrm{C}$ in $\mathrm{E} 3$ medium $(5 \mathrm{mM} \mathrm{NaCl}, 0.17 \mathrm{mM} \mathrm{KCl}, 0.33 \mathrm{mM} \mathrm{CaCl}, 0.33$ $\mathrm{mM}$ MgSO4, $\mathrm{pH}$ 7.6) supplemented with $30 \mu \mathrm{g} / \mathrm{mL}$ 1-phenyl-thiourea (Sigma), in order to inhibit melanin synthesis. Forty eight hours post-injection, the number of foci that had escaped the injection site were counted under an inverted confocal microscope Zeiss LSM 780, for each injected fish.

\section{Metastasis formation assay}


4T1 cells, adenocarcinoma cell line derived from the mammary glands of Balb/c mice, were cultured and maintained in $\alpha$-MEM supplemented with $10 \%$ fetal bovine serum, $1 \mathrm{mM}$ Penicillin/Streptomycin, and $1 \mathrm{mM}$ sodium pyruvate at $37^{\circ} \mathrm{C}$ in $5 \% \mathrm{CO}_{2}$ and $95 \%$ humidity. Stably knocked down 4T1 cells were generated by lentiviral infection with Bcl-X MISSION shRNA Lentiviral Clone (PLKO.1; Sigma-Aldrich). Stably infected cell populations were generated following Puromycin selection $(1 \mathrm{mg} / \mathrm{ml})$. Bcl-X expression levels were assessed by western blotting.

Experiments using mouse xenograft models were carried out by LMT (Laboratoire des Modèles Tumoraux, Centre Léon Bérard, Lyon, France). For tail-vein injection, $1,5 \times 10^{5}$ cells suspended in 100 $\mu$ I PBS were injected into the tail vein of 7-week-old female BALBC mice. Lungs were collected for histological analysis 21 days after tail-vein injection. All animal studies were conducted in accordance with European Union guidelines and approved by the local ethics committee.

\section{Immunofluorescence}

Cells were transfected with an ER-targeting GFP and seeded onto a glass coverslip. Cells were then incubated with Mitotracker deep red (Life technologies) for $20 \mathrm{~min}$ in the incubator, followed by a $20 \mathrm{~min}$ wash with culture medium in the incubator. Cells were fixed with $4 \%$ paraformaldehyde (PFA, EMS) for $20 \mathrm{~min}$ at $37^{\circ} \mathrm{C}$. After 3 washes with PBS, cells were permeabilised and saturated in a 0.1\% Triton 0.3\% BSA PBS solution for $20 \mathrm{~min}$. Cells were subsequently incubated for $1 \mathrm{~h}$ with primary antibody and $1 \mathrm{~h}$ with Alexa fluor 563 coupled secondary antibody. Each incubation with the antibodies was followed by three washes with a $0.1 \%$ Triton PBS solution. Coverslips were mounted with a Dako mounting medium. Images were acquired using an inverted Zeiss LSM 780 confocal microscope.

\section{Apoptosis assay}

3,000 cells per well were seeded onto a 96-well plate, each condition was prepared in triplicate. The next morning, medium was replaced with fresh medium, containing Incucyte Caspase $3 / 7$ reagent (Essen Bioscience) and $1 \mu \mathrm{M}$ staurosporine (Sigma) or DMSO. The plate was then incubated in the Incucyte Zoom imaging system and scanned every hour for $24 \mathrm{~h}$, scanning one field 
per well. Images were analysed using the Incucyte zoom software and caspase activation was calculated by dividing the number of green counts per image by the cell confluence mask.

\section{Subcellular fractionation}

Hs578T cells were harvested by trypsinisation and homogenized in MB buffer $(210 \mathrm{mM}$ mannitol, 70mM sucrose, $1 \mathrm{mM}$ EDTA and 10mM HEPES (pH 7.4) containing protease inhibitors), by shearing with a $1 \mathrm{~mL}$ syringe and a $26 \mathrm{G} 5 / 8$ needle 20 times. Actual homogenization was visually assessed under the microscope. All steps were carried out at $4^{\circ} \mathrm{C}$. Cell extracts were centrifuged 3 times $10 \mathrm{~min}$ at $1,500 \mathrm{~g}$ to remove the nuclear fraction (grey). Supernatants were then centrifuged 3 times $10 \mathrm{~min}$ at $10,600 \mathrm{~g}$. After the third round of centrifugation, yellowish MAM upper pellet (yellowish) and pure mitochondria lower pellet (brownish) were carefully collected with a micropipette and resuspended in MB buffer, whereas the supernatant was centrifuged again for $1 \mathrm{~h}$ at $100,000 \mathrm{~g}$. After this last round of centrifugation, the obtained microsome pellet was resuspended in RIPA buffer. The purity of obtained fractions was assessed by Western blot.

\section{Measurement of oxygen consumption rate (OCR) and OCR/ECAR ratio}

OCR and OCR/ECAR ratio were measured using the Seahorse Bioscience XF24 Extracellular Flux Analyser (Seahorse Bioscience, North Billerica, MA) according to the manufacturer's protocol. Cells were seeded in standard growth medium $24 \mathrm{~h}$ before measurement at a density of $3 \times 10^{4}$ cells for Hs578T wild type (WT) cells and $3.5 \times 10^{4}$ per well for Bcl-xL KO Hs578T cells. The assay was performed in DMEM high glucose medium without sodium bicarbonate (Gibco) supplemented with $10 \% \mathrm{FBS}$ at $\mathrm{pH}$ 7.4. Cells were washed twice and pre-incubated in this medium for $1 \mathrm{~h}$ before measurement at $37^{\circ} \mathrm{C}$ in a damp atmosphere without $\mathrm{CO}_{2} .0 .5 \mu \mathrm{M}$ Oligomycin $\mathrm{D}$ (Enzo life sciences, USA), $1 \mu \mathrm{M}$ FCCP (Sigma-Aldrich, USA), $0.5 \mu \mathrm{M}$ rotenone (Sigma-Aldrich, USA), $0.5 \mu \mathrm{M}$ antimycin A (Sigma-Aldrich, USA) were used to evaluate mitochondrial respiratory capacity and glycolytic capacity. The data were normalised against the amount of protein present in the control wells. The final protein content of each well was typically $18-24 \mu \mathrm{g}$. Data were represented as the mean $+/-\mathrm{SD}$ 
of 4 independent biological experiments in which OCR and ECAR were measured in 5 or more Seahorse microplate wells.

\section{ATP measurements}

Intracellular ATP levels in Hs578t WT and Bcl-xL KO cells were assessed using ATP Assay Kit (Abcam) following manufacturer's instructions. A Clariostar microplate reader (BMG Labtech) was used to measure fluorescence (Ex/Em=535/587nm).

ATP production rate was calculated from the conversion of Oxygen consumption rate (OCR) and extracellular acidification rate (ECAR) measured in the Seahorse Bioscience XF24 Extracellular Flux Analyzer. A simple spreadsheet to calculate glycolytic and oxidative ATP production rates from raw extracellular acidification and respiration data is provided by Mookerjee et al (57).

In each well, oligomycin, and rotenone/Antimycin were added stepwise, and ECAR and OCR at each step were measured. As measured in Mookerjee et al (57), cells were assayed at $37^{\circ} \mathrm{C}$ at $\mathrm{pH}$ 7.4 with a buffering power of $0.045 \mathrm{mpH} / \mathrm{pmol}$ of $\mathrm{H}^{+}$. At $\mathrm{pH} 7.4$, the combined hydration/dissociation constant of $\mathrm{CO}_{2}$ to $\mathrm{HCO}_{3}^{-}+\mathrm{H}^{+}$is 6.093. We assumed similar $\mathrm{pH}$, buffering power and hydration/dissociation constant for our experiments

\section{ROS measurements}

The oxidative stress detection of $\mathrm{Hs578t}$ WT versus $\mathrm{Bcl}-\mathrm{xL} \mathrm{KO}$ cells and $\mathrm{Hs578t} \mathrm{Bcl}-\mathrm{xL} \mathrm{KO}$ versus Bcl-xL KO rescue Acta were performed with CellROX green reagent (ThermoFisher Scientific), or MitoSOX (ThermoFisher Scientific) for mitochondrial ROS. Cells were seeded at $40 \%$ confluence in 6-well plates and the grown overnight. $5 \mu \mathrm{M}$ of CellROX (life Technologies) was added for 30 minutes at $37^{\circ} \mathrm{C}$ and after 2 washes, cells were observed under the microscope. Images were acquired using a Zeiss 780 confocal microscope. Regarding MitoSOX, cells were seeded at $40 \%$ confluence in 6 -well plates and grown overnight. MitoSOX was added for 30 minutes at $37^{\circ} \mathrm{C}$ (final concentration $1 \mu \mathrm{M}$ ), cells were then centrifuged and resuspended in $300 \mu \mathrm{L}$ PBS. Fluorescence was measured by flow cytometry with a FACSCANTOII (BD) apparatus. 


\section{Mitochondrial mass}

Mitochondrial mass was measured using acridine orange 10-nonyl bromide (NAO, Sigma). Cells were seeded at $40 \%$ confluence in 6 -well plates and grown overnight. NAO was added for 30 minutes at $37^{\circ} \mathrm{C}$ (final concentration $10 \mathrm{nM}$ ). The cells were centrifuged and resuspended in $300 \mu \mathrm{L}$ of PBS. The fluorescence was analysed by flow cytometry with a FACSCANTOII (BD) apparatus.

\section{Intracellular calcium measurements}

For mitochondrial $\mathrm{Ca}^{2+}$ measurements of $\mathrm{KO}$ cell lines, pure mitochondria were collected as described above and resuspended in $\mathrm{KCl}$ buffer $\left(125 \mathrm{mM} \mathrm{KCl}, 2 \mathrm{mM} \mathrm{K}_{2} \mathrm{HPO}_{4}, 1 \mathrm{mM} \mathrm{MgCl}_{2}\right.$ and $20 \mathrm{mM}$ HEPES, pH 7) containing $5 \mu \mathrm{M}$ Oregon green $5 \mathrm{~N}$ probe. Fluorescence was measured using the Clariostar plate reader, following $20 \mu \mathrm{M} \mathrm{CaCl}_{2}$ injection. Mitochondrial $\mathrm{Ca}^{2+}$ uptake was evaluated as the decreasing slope of the fluorescence signal.

For mitochondrial $\mathrm{Ca}^{2+}$ measurements of cells loaded with peptides or $\mathrm{ER} \mathrm{Ca}^{2+}$ measurements, cells were transfected with cepia-2-mt or Rcepia 1-ER(58) probes, respectively, $48 \mathrm{~h}$ before starting the experiment. Cells were seeded in Labtech chambers and incubated with EM buffer $\left(121 \mathrm{mM} \mathrm{NaCl} ; 5.4 \mathrm{mM} \mathrm{KCl}, 2.6 \mathrm{mM} \mathrm{MgCl}\right.$ hexahydrate, $6 \mathrm{mM} \mathrm{NaHCO}_{3}, 5 \mathrm{mM}$ D-Glucose, 25 mM HEPES pH 7.3). Fluorescence was quantified with a Zeiss LSM 780 confocal microscope, following $100 \mu \mathrm{M}$ histamine injection.

For cytosolic $\mathrm{Ca}^{2+}$ measurements, 30,000 cells per well were seeded onto a 96-well plate the day before the experiment. The next day, cells were loaded with $5 \mu \mathrm{M}$ Fluoforte dye (Enzo) in EM buffer for $45 \mathrm{~min}$ at $37^{\circ} \mathrm{C}$. Fluoforte was washed once with EM buffer and fluorescence was measured using the Clariostar plate reader, following $100 \mu \mathrm{M}$ histamine injection.

\section{Peptides}

Peptides were obtained from Covalab (Lyon, France) and resuspended in sterile distilled water to a final concentration of $1 \mathrm{mM}$. TAT peptides were diluted at $100 \mu \mathrm{M}$ and incubated overnight at room temperature. On the day of the experiment, cells were washed once with EM buffer and 
incubated with EM-diluted peptides for $1 \mathrm{~h}$ in the incubator. Cells were then washed once with culture medium and were used for subsequent experiments.

The sequences of the peptides are as follows:

\section{Peptide BH4 Bcl-xL :}

1-CKRKKRRQRRRGGSGGMSQSNRELVVDFLSYKLSQKGYSW-40

\section{Peptide scrBH4 Bcl-xL :}

\section{1-CKRKKRRQRRRGGSGGWYSKQRSLSGLVMYVLEDKNSQFS-40}

Both peptides were covalently labelled with rhodamine (TAMRA flurorophore) at the level of the lysine residue at position 2 (bold), df-TAT sequence is in blue, linker is in red.

\section{Gene expression}

Gene expression was extracted from data generated by the TCGA Research Network: http://cancergenome.nih.gov/ or from the KM plotter database. Considering the TCGA database, the RSEM normalised expression values were analysed for BCL2 (herein referred to as $b c / 2$ ) and BCL2L1 (herein referred to as $b c / x$ ). Data were available for 1093 breast tumours and 98 adjacent healthy tissues. 806 patients were positive for oestrogen receptor while 237 were negative.

\section{Statistical analyses}

Regarding the genomic analysis, non-parametric tests were run to determine the p-value (either Wilcoxon or ANOVA). Kaplan Meier representation of the overall survival was plotted and a LogRank test was run to determine the p-value. Regarding all other experiments, Student t-tests were performed when comparing two means and ANOVA was used for comparison of three means or more.

\section{Acknowledgedments}

We would like to thank Stéphane Borel for technical assistance, Julien Prudent for critical reading of the manuscript, Brigitte Manship for manuscript editing, Isabelle Goddard for skillful 
technical assistance regarding studies in mice (LMT, Lyon), and CIQLE core facility (SFR Santé LyonEst) for videomicroscopy. This work was supported by AFM telethon (to GG, grant \# 20269) and Fondation ARC to GG (grant \# PGA1 RF20180206799) and JL (grant \# PJA 20161204606)

\section{Competing interests}

The authors declare no competing financial interests 


\section{References}

1. Youle RJ, Strasser A. The BCL-2 protein family: opposing activities that mediate cell death. Nat Rev Mol Cell Biol. 2008 Jan;9(1):47-59.

2. Lopez J, Tait SWG. Mitochondrial apoptosis: killing cancer using the enemy within. $\mathrm{Br}$ J Cancer. 2015 Mar 17;112(6):957-62.

3. Bonneau B, Prudent J, Popgeorgiev N, Gillet G. Non-apoptotic roles of Bcl-2 family: the calcium connection. Biochim Biophys Acta. 2013 Jul;1833(7):1755-65.

4. Prudent J, Popgeorgiev N, Bonneau B, Thibaut J, Gadet R, Lopez J, et al. Bcl-wav and the mitochondrial calcium uniporter drive gastrula morphogenesis in zebrafish. Nat Commun. 2013;4:2330.

5. Li C, Wang X, Vais H, Thompson CB, Foskett JK, White C. Apoptosis regulation by Bcl-x(L) modulation of mammalian inositol 1,4,5-trisphosphate receptor channel isoform gating. Proc Natl Acad Sci U S A. 2007 Jul 24;104(30):12565-70.

6. White C, Li C, Yang J, Petrenko NB, Madesh M, Thompson CB, et al. The endoplasmic reticulum gateway to apoptosis by Bcl-X(L) modulation of the InsP3R. Nat Cell Biol. 2005 Oct; $7(10): 1021-8$.

7. Huang $\mathrm{H}, \mathrm{Hu} \mathrm{X}$, Eno CO, Zhao G, Li C, White C. An interaction between Bcl-xL and the voltage-dependent anion channel (VDAC) promotes mitochondrial Ca2+ uptake. J Biol Chem. 2013 Jul 5;288(27):19870-81.

8. Vander Heiden MG, Li XX, Gottleib E, Hill RB, Thompson CB, Colombini M. Bcl-xL promotes the open configuration of the voltage-dependent anion channel and metabolite passage through the outer mitochondrial membrane. J Biol Chem. 2001 Jun 1;276(22):19414-9.

9. Vervliet T, Clerix E, Seitaj B, Ivanova H, Monaco G, Bultynck G. Modulation of Ca2+ Signaling by Anti-apoptotic B-Cell Lymphoma 2 Proteins at the Endoplasmic Reticulum-Mitochondrial Interface. Front Oncol. 2017;7:75.

10. Karczmarek-Borowska B, Filip A, Wojcierowski J, Smoleń A, Korobowicz E, KorszenPilecka I, et al. Estimation of prognostic value of Bcl-xL gene expression in non-small cell lung cancer. Lung Cancer Amst Neth. 2006 Jan;51(1):61-9.

11. Watanabe J, Kushihata F, Honda K, Mominoki K, Matsuda S, Kobayashi N. Bcl-xL overexpression in human hepatocellular carcinoma. Int J Oncol. 2002 Sep;21(3):515-9.

12. Olopade OI, Adeyanju MO, Safa AR, Hagos F, Mick R, Thompson CB, et al. Overexpression of BCL-x protein in primary breast cancer is associated with high tumor grade and nodal metastases. Cancer J Sci Am. 1997 Aug;3(4):230-7.

13. Martin SS, Ridgeway AG, Pinkas J, Lu Y, Reginato MJ, Koh EY, et al. A cytoskeletonbased functional genetic screen identifies Bcl-xL as an enhancer of metastasis, but not primary tumor growth. Oncogene. 2004 Jun 3;23(26):4641-5. 
14. Fernández Y, España L, Mañas S, Fabra A, Sierra A. Bcl-xL promotes metastasis of breast cancer cells by induction of cytokines resistance. Cell Death Differ. 2000 Apr;7(4):350-9.

15. Keitel U, Scheel A, Thomale J, Halpape R, Kaulfuß S, Scheel C, et al. Bcl-xL mediates therapeutic resistance of a mesenchymal breast cancer cell subpopulation. Oncotarget [Internet]. 2014 Nov 5 [cited 2014 Dec 18];5(0). Available from: http://www.impactjournals.com/oncotarget/index.php?journal=oncotarget\&page=article \&op=view\&path $\% 5 \mathrm{~B} \% 5 \mathrm{D}=2634$

16. Hager JH, Ulanet DB, Hennighausen L, Hanahan D. Genetic ablation of Bcl-x attenuates invasiveness without affecting apoptosis or tumor growth in a mouse model of pancreatic neuroendocrine cancer. PloS One. 2009;4(2):e4455.

17. Du Y-CN, Lewis BC, Hanahan D, Varmus H. Assessing tumor progression factors by somatic gene transfer into a mouse model: Bcl-xL promotes islet tumor cell invasion. PLoS Biol. 2007 Oct 16;5(10):e276.

18. Hwang K-T, Woo JW, Shin HC, Kim HS, Ahn SK, Moon H-G, et al. Prognostic influence of BCL2 expression in breast cancer. Int J Cancer J Int Cancer. 2012 Oct 1;131(7):E1109-1119.

19. Neve RM, Chin K, Fridlyand J, Yeh J, Baehner FL, Fevr T, et al. A collection of breast cancer cell lines for the study of functionally distinct cancer subtypes. Cancer Cell. 2006 Dec;10(6):515-27.

20. Schmitt E, Beauchemin M, Bertrand R. Nuclear colocalization and interaction between bcl-xL and cdk1(cdc2) during G2/M cell-cycle checkpoint. Oncogene. 2007 Aug 30;26(40):5851-65.

21. Ran FA, Hsu PD, Wright J, Agarwala V, Scott DA, Zhang F. Genome engineering using the CRISPR-Cas9 system. Nat Protoc. 2013 Nov;8(11):2281-308.

22. Teng Y, Xie X, Walker S, White DT, Mumm JS, Cowell JK. Evaluating human cancer cell metastasis in zebrafish. BMC Cancer. 2013 Oct 4;13:453.

23. Oltersdorf T, Elmore SW, Shoemaker AR, Armstrong RC, Augeri DJ, Belli BA, et al. An inhibitor of Bcl-2 family proteins induces regression of solid tumours. Nature. 2005 Jun 2;435(7042):677-81.

24. Lessene G, Czabotar PE, Sleebs BE, Zobel K, Lowes KN, Adams JM, et al. Structureguided design of a selective BCL-X(L) inhibitor. Nat Chem Biol. 2013 Jun;9(6):390-7.

25. Eno CO, Eckenrode EF, Olberding KE, Zhao G, White C, Li C. Distinct roles of mitochondria- and ER-localized Bcl-xL in apoptosis resistance and $\mathrm{Ca} 2+$ homeostasis. Mol Biol Cell. 2012 Jul;23(13):2605-18.

26. Bonneau B, Nougarède A, Prudent J, Popgeorgiev N, Peyriéras N, Rimokh R, et al. The Bcl-2 homolog Nrz inhibits binding of IP3 to its receptor to control calcium signaling during zebrafish epiboly. Sci Signal. 2014 Feb 11;7(312):ra14. 
27. Banaszynski LA, Chen L, Maynard-Smith LA, Ooi AGL, Wandless TJ. A Rapid, Reversible, and Tunable Method to Regulate Protein Function in Living Cells Using Synthetic Small Molecules. Cell. 2006 Sep 8;126(5):995-1004.

28. Monaco G, Decrock E, Arbel N, van Vliet AR, La Rovere R, De Smedt H, et al. The $\mathrm{BH} 4$ domain of anti-apoptotic Bcl-XL, but not that of the related Bcl-2, limits the voltage-dependent anion channel 1 (VDAC1)-mediated transfer of pro-apoptotic $\mathrm{Ca} 2+$ signals to mitochondria. J Biol Chem. 2015 Feb 13;

29. Shimizu S, Konishi A, Kodama T, Tsujimoto Y. BH4 domain of antiapoptotic Bcl-2 family members closes voltage-dependent anion channel and inhibits apoptotic mitochondrial changes and cell death. Proc Natl Acad Sci U S A. 2000 Mar 28;97(7):3100-5.

30. Tsujimoto Y, Shimizu S. VDAC regulation by the Bcl-2 family of proteins. Cell Death Differ. 2000 Dec;7(12):1174-81.

31. Dogterom M, Koenderink GH. Actin-microtubule crosstalk in cell biology. Nat Rev Mol Cell Biol. 2019 Jan;20(1):38-54.

32. Senju Y, Lappalainen P. Regulation of actin dynamics by PI(4,5)P2 in cell migration and endocytosis. Curr Opin Cell Biol. 2019 Feb;56:7-13.

33. Angelova PR, Abramov AY. Functional role of mitochondrial reactive oxygen species in physiology. Free Radic Biol Med. 2016;100:81-5.

34. Kastl L, Sauer SW, Ruppert T, Beissbarth T, Becker MS, Süss D, et al. TNF- $\alpha$ mediates mitochondrial uncoupling and enhances ROS-dependent cell migration via NF- $\kappa \mathrm{B}$ activation in liver cells. FEBS Lett. 2014 Jan 3;588(1):175-83.

35. Lim S-K, Choi YW, Lim IK, Park TJ. BTG2 suppresses cancer cell migration through inhibition of Src-FAK signaling by downregulation of reactive oxygen species generation in mitochondria. Clin Exp Metastasis. 2012 Dec;29(8):901-13.

36. Ludin A, Gur-Cohen S, Golan K, Kaufmann KB, Itkin T, Medaglia C, et al. Reactive oxygen species regulate hematopoietic stem cell self-renewal, migration and development, as well as their bone marrow microenvironment. Antioxid Redox Signal. 2014 Oct 10;21(11):1605-19.

37. Vander Heiden MG, Chandel NS, Schumacker PT, Thompson CB. Bcl-xL prevents cell death following growth factor withdrawal by facilitating mitochondrial ATP/ADP exchange. Mol Cell. 1999 Feb;3(2):159-67.

38. Chen Y, Aon MA, Hsu Y-T, Soane L, Teng X, McCaffery JM, et al. Bcl-xL regulates mitochondrial energetics by stabilizing the inner membrane potential. J Cell Biol. 2011 Oct 17;195(2):263-76.

39. Hardwick JM, Chen Y, Jonas EA. Multipolar functions of BCL-2 proteins link energetics to apoptosis. Trends Cell Biol. 2012 Jun;22(6):318-28.

40. Prevarskaya N, Skryma R, Shuba Y. Calcium in tumour metastasis: new roles for known actors. Nat Rev Cancer. 2011 Jul 22;11(8):609-18. 
41. Paupe V, Prudent J. New insights into the role of mitochondrial calcium homeostasis in cell migration. Biochem Biophys Res Commun. 2018 27;500(1):75-86.

42. Nguyen M-HT, Jafri MS. Mitochondrial calcium signaling and energy metabolism. Ann N Y Acad Sci. 2005 Jun;1047:127-37.

43. Griffiths EJ, Rutter GA. Mitochondrial calcium as a key regulator of mitochondrial ATP production in mammalian cells. Biochim Biophys Acta. 2009 Nov;1787(11):1324-33.

44. Ben-Hail D, Shoshan-Barmatz V. VDAC1-interacting anion transport inhibitors inhibit VDAC1 oligomerization and apoptosis. Biochim Biophys Acta. $2016 \mathrm{Jul} ; 1863(7 \mathrm{Pt}$ A):1612-23.

45. Choi S, Chen Z, Tang LH, Fang Y, Shin SJ, Panarelli NC, et al. Bcl-xL promotes metastasis independent of its anti-apoptotic activity. Nat Commun. 2016 Jan 20;7:10384.

46. Vogler M, Hamali HA, Sun X-M, Bampton ETW, Dinsdale D, Snowden RT, et al. BCL2/BCL-X(L) inhibition induces apoptosis, disrupts cellular calcium homeostasis, and prevents platelet activation. Blood. 2011 Jun 30;117(26):7145-54.

47. González-García M, Pérez-Ballestero R, Ding L, Duan L, Boise LH, Thompson CB, et al. bcl-XL is the major bcl-x mRNA form expressed during murine development and its product localizes to mitochondria. Dev Camb Engl. 1994 Oct;120(10):3033-42.

48. Motoyama N, Wang F, Roth KA, Sawa H, Nakayama K, Nakayama K, et al. Massive cell death of immature hematopoietic cells and neurons in Bcl-X-deficient mice. Science. 1995 Mar 10;267(5203):1506-10.

49. Johnson BW, Cepero E, Boise LH. Bcl-xL inhibits cytochrome c release but not mitochondrial depolarization during the activation of multiple death pathways by tumor necrosis factor-alpha. J Biol Chem. 2000 Oct 6;275(40):31546-53.

50. Popgeorgiev N, Jabbour L, Gillet G. Subcellular Localization and Dynamics of the Bcl-2 Family of Proteins. Front Cell Dev Biol. 2018;6:13.

51. Yang J, Vais H, Gu W, Foskett JK. Biphasic regulation of InsP3 receptor gating by dual $\mathrm{Ca} 2+$ release channel BH3-like domains mediates Bcl-xL control of cell viability. Proc Natl Acad Sci U S A. 2016 Mar 14;

52. Fouqué A, Lepvrier E, Debure L, Gouriou Y, Malleter M, Delcroix V, et al. The apoptotic members CD95, BclxL, and Bcl-2 cooperate to promote cell migration by inducing $\mathrm{Ca}(2+)$ flux from the endoplasmic reticulum to mitochondria. Cell Death Differ. 2016 Oct;23(10):1702-16.

53. Shimizu S, Narita M, Tsujimoto Y. Bcl-2 family proteins regulate the release of apoptogenic cytochrome $\mathrm{c}$ by the mitochondrial channel VDAC. Nature. 1999 Jun 3;399(6735):483-7.

54. Rostovtseva TK, Tan W, Colombini M. On the role of VDAC in apoptosis: fact and fiction. J Bioenerg Biomembr. 2005 Jun;37(3):129-42. 
55. Tan W, Colombini M. VDAC closure increases calcium ion flux. Biochim Biophys Acta. 2007 Oct;1768(10):2510-5.

56. Popgeorgiev N, Bonneau B, Ferri KF, Prudent J, Thibaut J, Gillet G. The apoptotic regulator Nrz controls cytoskeletal dynamics via the regulation of $\mathrm{Ca} 2+$ trafficking in the zebrafish blastula. Dev Cell. 2011 May 17;20(5):663-76.

57. Mookerjee SA, Gerencser AA, Nicholls DG, Brand MD. Quantifying intracellular rates of glycolytic and oxidative ATP production and consumption using extracellular flux measurements. J Biol Chem. 2017 28;292(17):7189-207.

58. Suzuki J, Kanemaru K, Ishii K, Ohkura M, Okubo Y, Iino M. Imaging intraorganellar $\mathrm{Ca} 2+$ at subcellular resolution using CEPIA. Nat Commun. 2014 Jun 13;5:4153. 


\section{Figure legends}

\section{Figure 1. Bcl-xL protein levels in human breast epithelial cell lines}

Western blotting showing $\mathrm{Bcl}-\mathrm{xL}$ protein levels in breast cancer cell lines. In the non tumorigenic breast epithelial cell line, MCF10A, Bcl-xL levels are low, with respect to breast cancer cell lines. Calnexin was used for calibration purposes.

\section{Figure 2. High $b c l x$ gene expression level is of poor prognosis in oestrogen receptor-positive}

\section{patients}

A. Boxplot representating $b c / x$ (left) and $b c / 2$ (right) expression values (RSEM) in breast tumours of the TCGA database (logarithmic values). The expression of $b c / x$ is higher in tumours $(N=1093)$ than adjacent healthy tissues $(\mathrm{N}=98)$ (left).

B. Left panel: $b c / 2$ expression levels in estrogen receptor (ER)-positive tumours ( $N=806 E R^{+}, N=237$ $\left.E R^{-}\right)$. Right panels: plots (TCGA, KM) showing that $b c / 2$ expression is indicative of better prognosis in ER-positive patients.

C. Left panel: $b c / x$ expression levels in estrogen receptor (ER)-positive tumours ( $N=806 E R^{+}, N=237$ $\left.E R^{-}\right)$. Right panels: plots (TCGA, KM) showing that $b c / x$ expression is indicative of a poorer prognosis in ER-positive patients. Corresponding $\mathrm{p}$ values are indicated for each plots. NS stands for nonsignificant.

\section{Figure 3. Bclx silencing impairs migration of mammary cancer cell lines}

A. siRNA-mediated knockdown of $b c l x$ in Hs578T cells as assessed by Western blot analysis. Tubulin was used as a loading control.

B. Representative trajectories of individual Hs578T cells during a $24 \mathrm{~h}$ single cell tracking experiment. Cells were incubated for $48 \mathrm{~h}$ in the presence of either scrambled siRNA (scr) or siRNA targeting $b c / x$ transcripts (siRNA1, 2), and subsequently seeded on an Essen lock 24-well plate. The plate was transferred to the Incucyte Zoom device and one picture was taken every 30 min for $24 \mathrm{~h}$. Each coloured line represents the path of one individual cell. Each panel displays superimposed paths of twenty individual cells. Representative results from three independent experiments.

C. Quantification of the single-cell tracking results displayed in B. Error bars represent the SEM of three independent experiments.

D. Measurement of cell invasiveness (Boyden chamber assay). Corresponding cells were seeded in the upper compartment ( $1 \%$ serum) while the lower compartment was filled with the same medium 
containing $10 \%$ serum. The number of cells having reached the lower compartment was measured after $7 \mathrm{~h}$ and $30 \mathrm{~min}$ incubation (membrane bottom). Each experimental measurement was performed in duplicate. Error bars represent the SEM of three independent experiments.

E. Successful CRISPR-Cas9-mediated KO of $b c l x$ was assessed by Western blot in Hs578T cells (upper panel) and MDA-MB231 cells (lower panel). KO and control cell lines were generated by infecting cells with a vector expressing or not the $b c / x$ sgRNA, respectively. Tubulin and Vinculin were used as loading controls.

F. Hs578T (dotted bars) or MDA-MB231 (solid bars) cell lines were subjected to single-cell tracking experiments and cell speed was quantified. Each KO cell line speed was compared to the corresponding empty vector control cell line. In all experiments, measurements were systematically performed in duplicate. Error bars represent the SEM of three independent experiments.

G. Representative images of the zebrafish invasion assay. At t0, equal amounts of control (Ctl, red) and $b c / x$ KO Hs578T (KO, green) cells were injected into the yolk of $24 \mathrm{~h}$-old zebrafish embryos. Embryos were then incubated at $30^{\circ} \mathrm{C}$ for $48 \mathrm{~h}$ before the fluorescent cell foci that had escaped the injection site were counted under a fluorescent microscope. Invading cell foci were mostly observed in the tail. Scale bar: $100 \mu \mathrm{m}$, except for the enlarged picture were scale bar represents $500 \mu \mathrm{m}$.

H. Mean number of cell foci that escaped the injection site. Error bars represent the SEM of four independent experiments.

Figure 4. Bclx silencing inhibits the ability of $4 T 1$ cells to metastasize to the lung

A. Immunoblotting of the expression of Bcl-xL in 4T1 control-shRNA and $b c / x$-shRNA cells.

B. Total number of lung metastatic nodules in each mouse in each group ( $n=7$ for $4 T 1$ controlshRNA cells and n=10 for $4 \mathrm{~T} 1 \mathrm{bc}(\mathrm{x}$-shRNA cells) were counted using a dissection scope. Data were expressed as the means \pm standard deviations and then compared among groups by analysis of variance (ANOVA).

C. Representative images and H\&E staining sections of mouse lung lobes 21 days after tail vein injection of 4T1 control-shRNA or bclx-shRNA cells. Scale bar : $200 \mu \mathrm{m}$. N, Normal lung tissue; M, metastatic nodule.

\section{Figure 5. Bcl-xL controls cell migration independently of its anti-apoptotic activity}

A. Caspase activation was measured in Hs578T cells transfected with siRNA control (scr) or siRNAs targeting $b c l-x$ transcripts. Transfected cells were incubated with the Caspase 3/7 probe (Essen) which emits green fluorescence when caspases are activated. Cells were incubated in an Incucyte Zoom device and mean caspase activation was quantified using the Incucyte software after $9 \mathrm{~h}$ 
incubation. Cells transfected with control siRNA and incubated with $1 \mu \mathrm{M}$ staurosporine (STS) were used as a positive control. Each experimental measurement was performed in triplicate. Error bars represent the SEM of three independent experiments.

B. Hs578T cells transfected with siRNA control (scr) or siRNAs targeting Bcl-xL were subjected to single cell tracking experiments in the presence (zVAD $10 \mu \mathrm{M}$ ) or in the absence (no zVAD) of the pan-caspase inhibitor zVAD-FMK $(10 \mu \mathrm{M})$. Mean cell speed was quantified for each condition. All experimental measurements were performed in duplicate. Error bars represent the SEM of three independent experiments.

C: Representative trajectories of individual $\mathrm{Hs} 578 \mathrm{~T}$ cells during a $24 \mathrm{~h}$ cell tracking experiment. Hs578T cells were seeded on an Essen lock 24-well plate. Before incubating the plate in the IncuCyte Zoom device, cells were treated with $10 \mu \mathrm{M}$ of BH3-mimetics (ABT-737, ABT-263 and WEHI539) or with vehicle (DMSO). Each colored line represents the path of one individual cell. Each panel displays superimposed paths of twenty individual cells. Representative results from three independent experiments are shown.

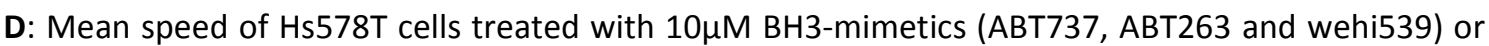
with vehicle (DMSO). Cells were subjected to single-cell tracking to quantify cell speed. All measurements were performed in duplicate. Error bars represent the SEM of three independent experiments.

Figure 6. Mitochondrial-, but not ER-targeted Bcl-xL, rescues cell migration

A. Immunofluorescence detection of recombinant Bcl-xL-Acta and Bcl-xL-Cb5 in Hs578T cells. First, the expression of DD-Bcl-xL ActA (mitochondrial) or DD-Bcl-xL CB5 (ER-targeted) was induced overnight using $0,1 \mu \mathrm{M}$ shield1 ligand. Cells were then immune-stained using an anti-Bcl-xL antibody. Mitochondria and ER were visualised with Mitotracker deep red and transfected ER-targeted GFP, respectively. Scale bar: $10 \mu \mathrm{m}$.

B. Profile plot calculated from fluorescence signals. Using ImageJ software, segments were drawn that virtually crossed cells from side to side (white dashes, merge panels, Fig. 4B). Fluorescence intensity along segments was quantified with ImageJ.

C. Left panel. Bcl-xL expression in bclx KO HT578 cells stably transfected with empty vector or expression vectors for $\mathrm{Bcl}-\mathrm{xL}, \mathrm{Bcl}-\mathrm{xL}-\mathrm{Acta}$ and $\mathrm{Bcl}-\mathrm{xL}-\mathrm{Cb} 5$. Expression of DD-Flag-Bcl-xL constructs was induced in each cell line by treating the cells with $0,1 \mu \mathrm{M}$ shield1 ligand overnight. The next morning, cell lysates were collected and subjected to Western blotting. Tubulin was used as a loading control. Right panel. Principle of the ProteoTuner inducible system. The protein of interest is fused to a destabilisation domain (DD). In the absence of the shield1 ligand, the protein is targeted to the 
proteasome via the DD, and rapidly degraded. Upon ligand of the addition, the protein of interest is stabilised and accumulates.

D: Rescue experiments. Corresponding Hs578T cell lines were subjected to single-cell tracking experiments, with or without treatment with $0,1 \mu \mathrm{M}$ shield1 ligand. For cell speed quantification each measurement was performed in duplicate. For each cell line, migration rescue percentage was calculated as the variation of cell speed between cells treated with the ligand (e.g. expressing the corresponding $\mathrm{Bcl}-\mathrm{xL}$ protein) and untreated cells from the same cell line (e.g. no $\mathrm{Bcl}-\mathrm{xL}$ protein expression). The calculated percentage was then compared to the control cell line (bclx KO + empty vector, yellow).

Figure 7. Mito-Bcl-xL forsters cell migration contrary to ER-Bcl-xL

A. Representative images of the zebrafish invasion assay (ProteoTuner inducible system). Phase contrast images are shown on the left. At $\mathrm{t}=0$, equal amounts of Hs578T expressing mitochondriaaddressed $\mathrm{Bcl}-\mathrm{xL}$ (ActA, red) or ER-addressed $\mathrm{Bcl}-\mathrm{xL}$ (CB5, green) were injected into the yolk of $48 \mathrm{~h}$ old zebrafish embryos (top panels). Embryos were then incubated at $30^{\circ} \mathrm{C}$ for $24 \mathrm{~h}$ before the fluorescent cells that had escaped the injection site were counted under the microscope. Invading cell foci were observed in the tail (bottom panels, white arrowheads). Scale bar: $100 \mu \mathrm{m}$.

B. Number of cell foci per fish that escaped the injection site. Error bars represent the SEM of three independent experiments.

C. Volume of tumor cell mass injected in the yolk and measure 24 hours post injection. Error bars represent the SEM of three independent experiments.

\section{Figure 8. Bcl-xL controls cell migration via its $\mathrm{BH} 4$ domain}

A. Table recapitulating the sequences of the TAT peptides used in this study.

B. Hs578T cells were loaded with $5 \mu \mathrm{M}$ of either TAT BH4 or TAT scrBH4 fluorescent peptides. Penetrance of the peptides was assessed by visualising fluorescent cells (red, false colours). Scale bars $=200 \mu \mathrm{m}$.

C. Hs578T cells loaded with $5 \mu \mathrm{M}$ of either TAT BH4 or TAT scrBH4 fluorescent peptides were subjected to single-cell tracking experiment. For cell speed quantification experiments, all measurements were performed in duplicate. Error bars represent the SEM of three independent experiments. 


\section{Figure 9. Bclx silencing alters mitochondrial ATP generation}

A. Representative diagram of oxygen consumption rate $(O C R)$ as analysed by a Seahorse Bioscience XF24 Extracellular Flux Analyser in Hs578t control cells (WT) and Hs578t bclx KO cells. OCR was measured continuously throughout the experiment, before (baseline) and after addition of the indicated drugs. A: Oligomycin D $(0.5 \mu \mathrm{M}), \mathrm{B}$ : FCCP $(1 \mu \mathrm{M})$; C: Antimycin A $(0.5 \mu \mathrm{M})+$ Rotenone $(0.5$ $\mu \mathrm{M})$.

B. Basal OCR as calculated from the mean of 8 baseline readings (mean +/- SD of $\mathrm{N}=4$ independent experiments). Data were normalised for each experiment against the mean obtained in control cells (WT).

C. Coupling efficiency of Hs578t control (WT) and $b c / x$ KO cells as calculated from the difference between OCR values measured before (basal) and after oligomycin addition (mean +/- SD of $N=4$ independent experiments). For each experiment, data were normalised against the mean obtained in WT cells.

D. OCR to ECAR ratio analysed by a Seahorse Bioscience XF24 Extracellular Flux Analyser in Hs578t WT cells and Hs578t $b c / x$ KO cells. OCR to ECAR ratio was calculated using the mean of 8 baseline readings (mean +/- SD of $n=4$ independent experiments). For each experiment, data were normalised to the mean obtained in WT cells.

E. Direct ATP measurement. Total ATP levels in Hs578t WT and $b c l x$ KO cells (mean \pm SD of $n=3$ independent experiments).

F. Percentage of ATP production rate from glycolysis (ATPglyc) or oxidative phosphorylation (ATPox) of Hs578t WT and $b c l-x$ KO cells (mean $+/-$ SD of $\mathrm{N}=4$ independent experiments). Statistical test: two-tailed Student test. ${ }^{* *} P<0.005, * * P<0.01, * P<0.05$, N.S.: non-significant. 


\section{Figure 10. Cell motility alterations and drop in ROS production are closely correlated}

A. Mean movement speed $(\mu \mathrm{m} / \mathrm{min})$ of Hs578T cells treated or not with $100 \mu \mathrm{M}$ Mitotempo ROS scavenger for $24 \mathrm{~h}$. Error bars represent the SEM from forty independent tracking of individual cells.

B. Representative behavior of Hs578T cells treated with or without $100 \mu \mathrm{M}$ Mitotempo for 24h. Each line represents the path of one individual cell. Superimposed paths from forty individual cells are displayed in each panel.

C. ROS measurement in control or bcl-x KO Hs578T cells, using CellROX dye. Values obtained from $b c / x$ KO cells were arbitrarily set at $100 \%$ for calibration purposes. Error bars represent SEM from three independent experiments.

D. ROS measurements from Hs578T bclx KO cells transfected or not with Bcl-xL-acta expression vector, using CellROX dye. Values obtained from control cells were arbitrarily set at $100 \%$ for calibration purposes. Error bars represent SEM from four independent experiments.

\section{Figure 11. Bclx silencing compromises calcium homeostasis}

A. $\mathrm{Ca}^{2+}$ uptake by isolated mitochondria. Mitochondria from control or bclx KO Hs578T cells were isolated by subcellular fractionation. Isolated mitochondria were then incubated in an Oregon green $5 \mathrm{~N}$-containing medium in multi well microplates. Vertical axis corresponds to fluorescence intensity (arbitrary units) as measured in a BMG Labtech microplate reader before and after addition of $\mathrm{CaCl}_{2}$ into the medium. Representative results from three independent experiments.

B. $\mathrm{Ca}^{2+}$ uptake by mitochondria from control or bclx KO Hs578T cells calculated from the slope of fluorescence intensity decrease in the extramitochondrial medium (see Fig. 8A). Values obtained from the control cell line were arbitrarily set at 1 for calibration purposes. Error bar represents the SEM of three independent experiments.

C: Representative response curve of Hs578T cells loaded with $5 \mu \mathrm{M}$ of either TAT BH4 or TAT scr BH4 peptides. $48 \mathrm{~h}$ before starting experiments, cells were transfected with the fluorescent mitochondrial probe Cepia 2 MT. Fluorescence was measured under a confocal microscope before and after histamine injection.

D. Maximal mitochondrial fluorescence signal relative to control from Hs578T cells loaded with TAT BH4 or TAT scr BH4 peptides $(5 \mu \mathrm{M})$ and transfected with mitochondrial probe Cepia 2 MT. Measurements were performed on at least forty cells per condition. Error bars represent the SEM of three independent experiments. 


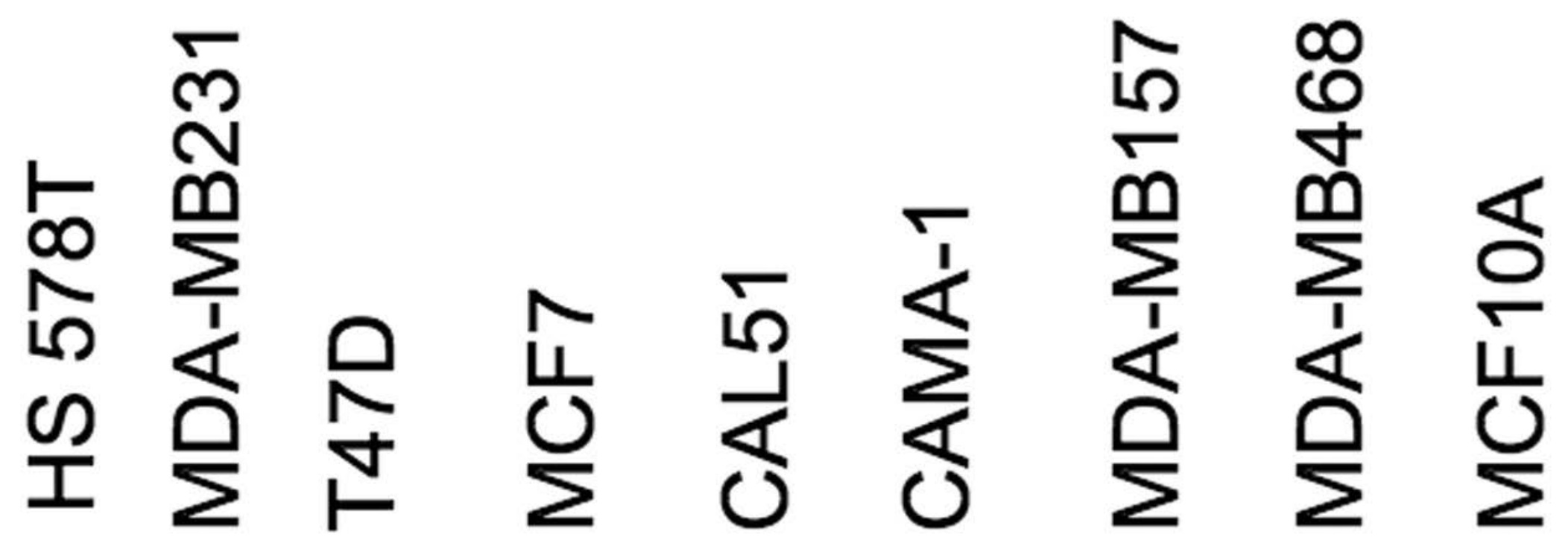

Bcl-xL

Actin 


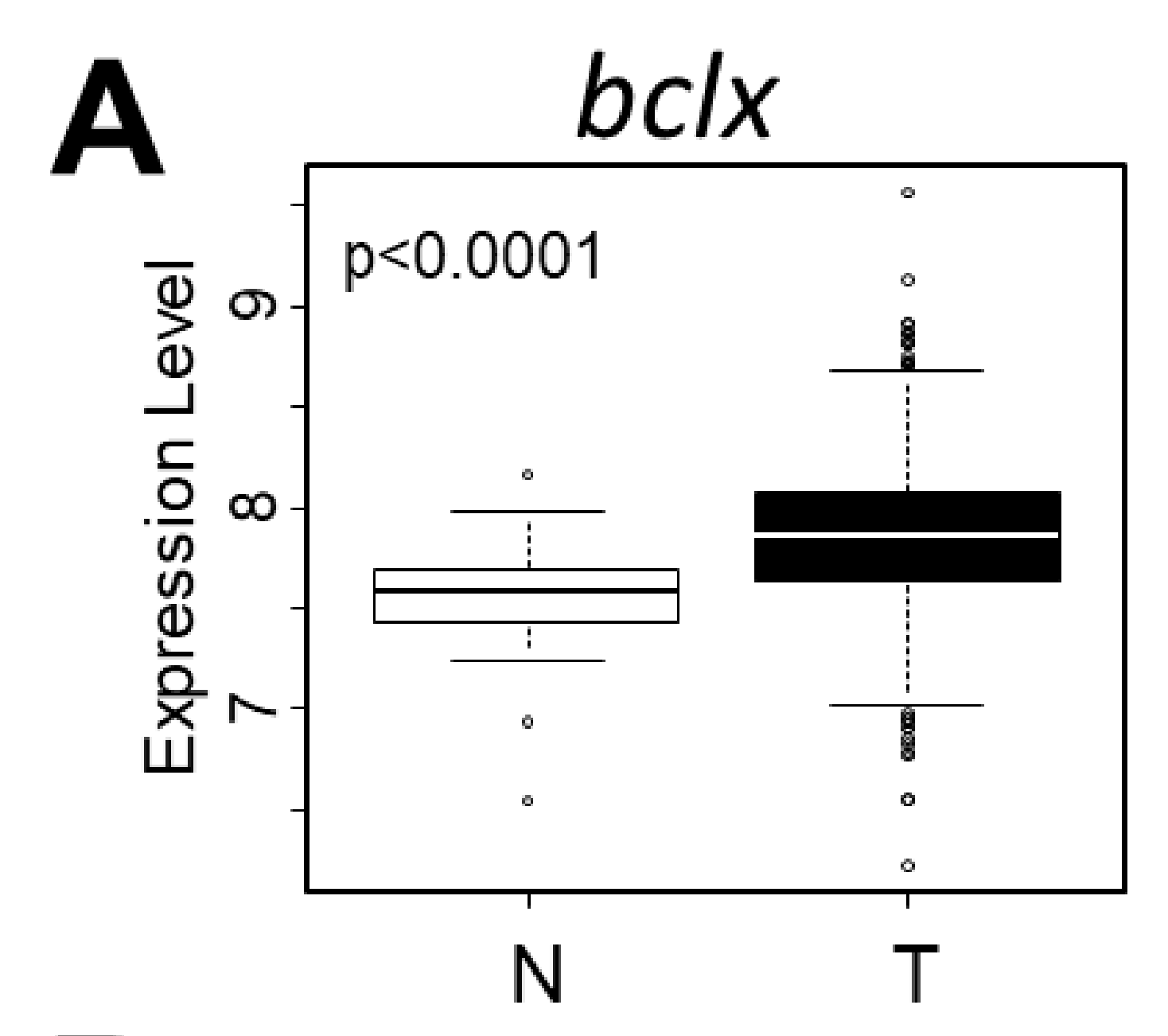

B
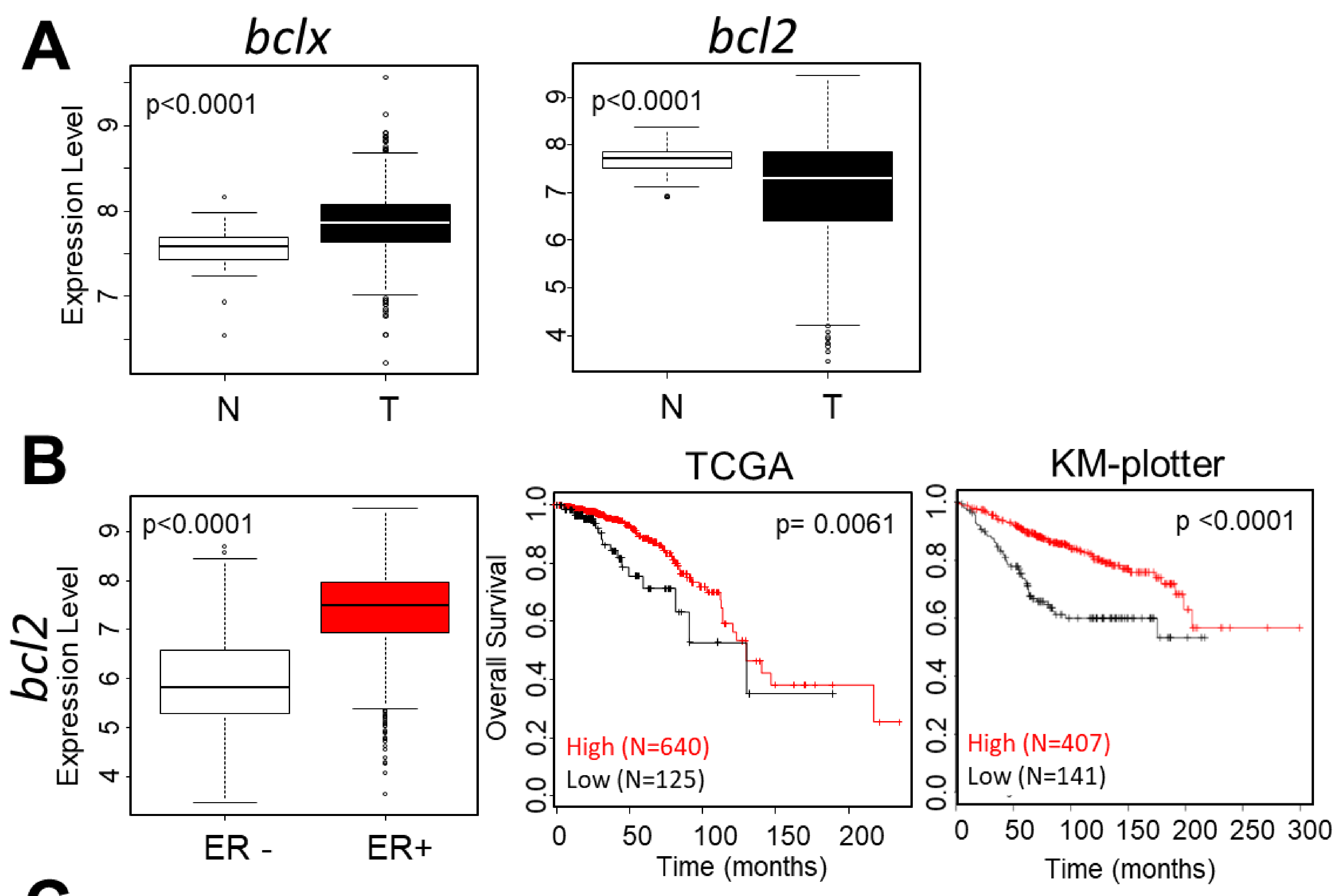

0
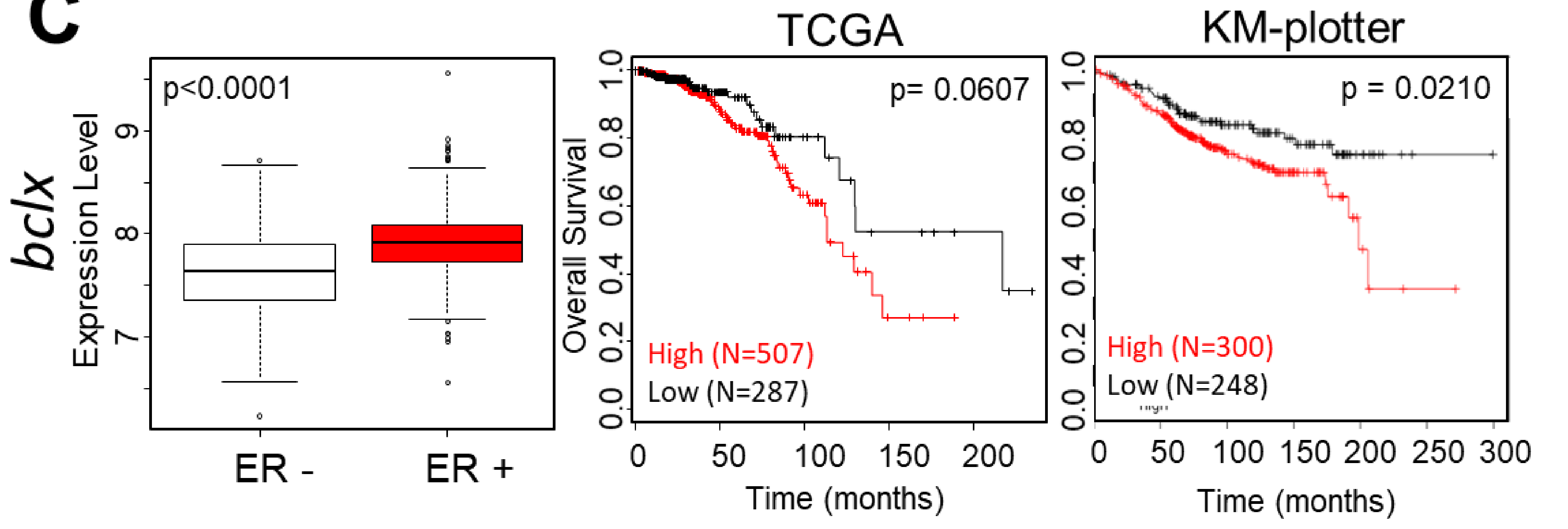


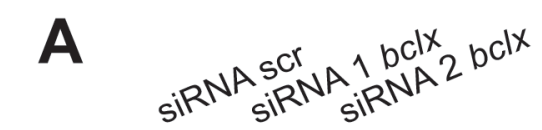
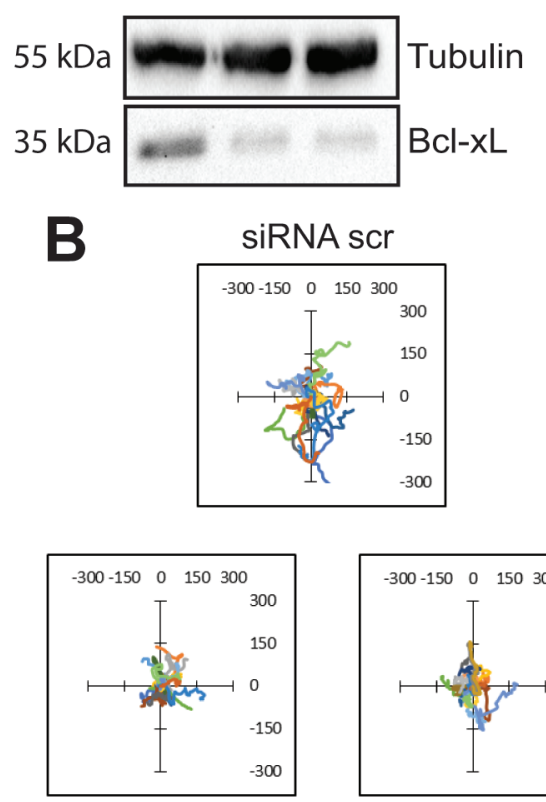

siRNA $1 \mathrm{bcl} x$
C

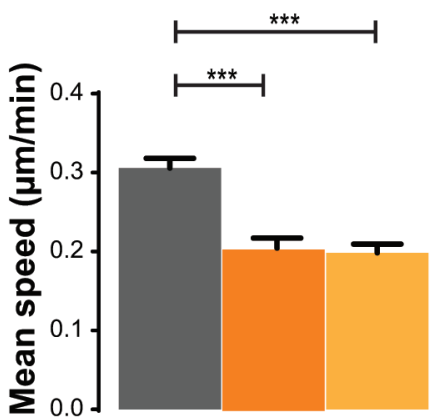

D

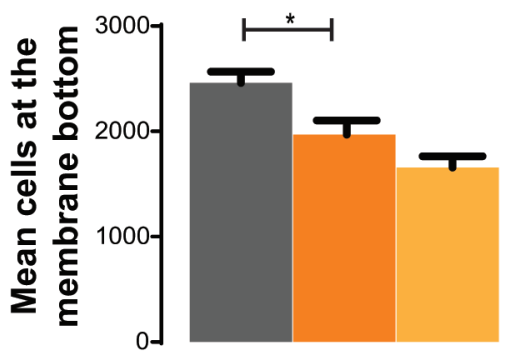

Hs578T

siRNA scr

siRNA $1 b c / x$

siRNA $2 b c / x$

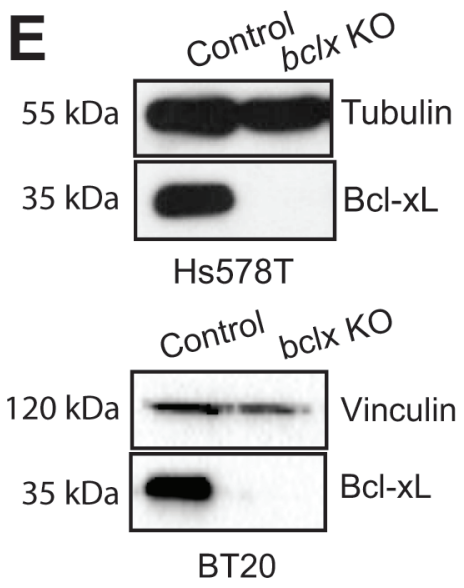

F
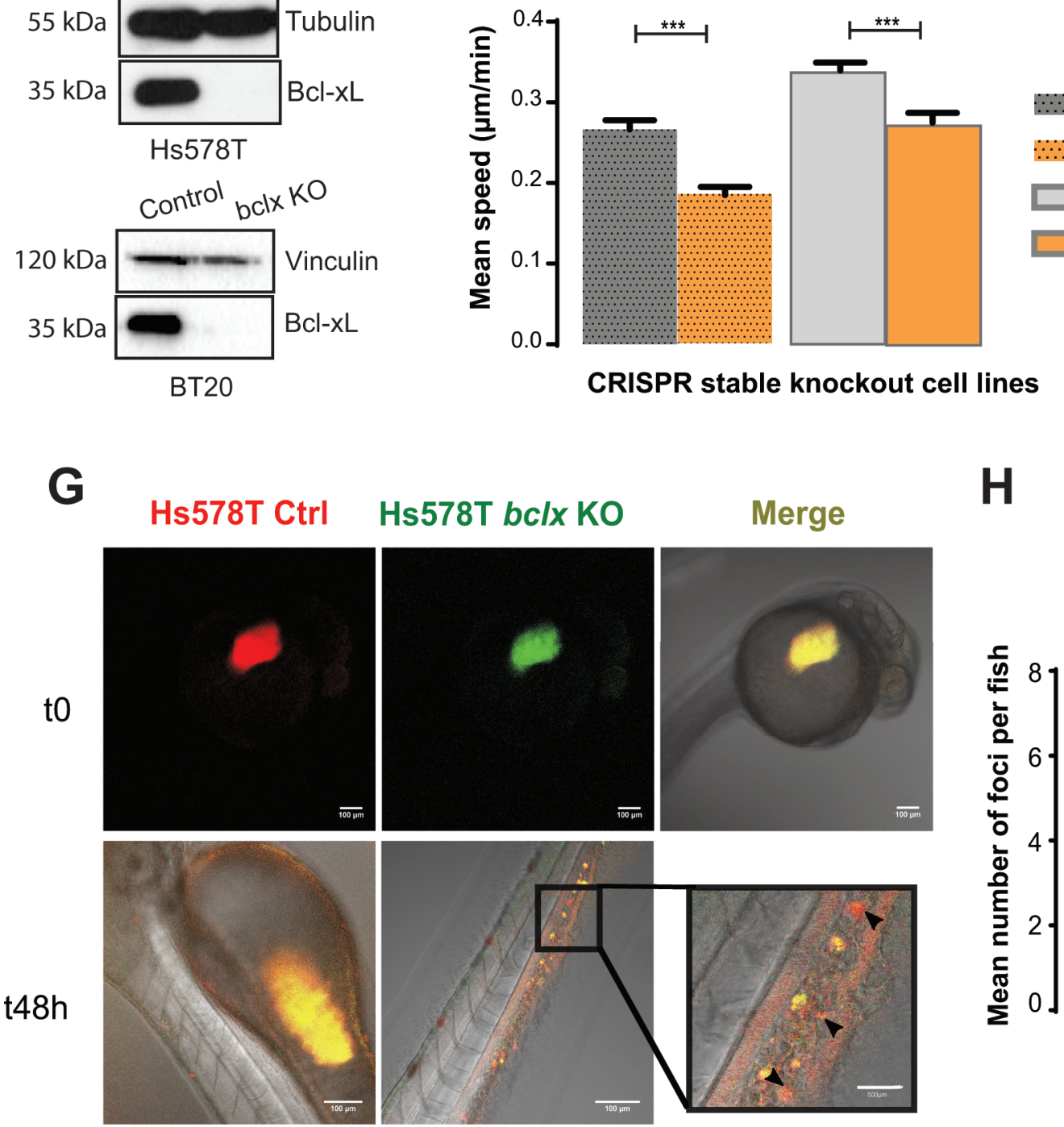

H

Hs578T

Control

$b c / x \mathrm{KO}$

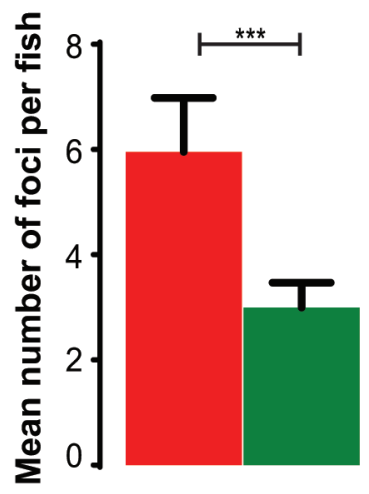

Injection site (vitellus)
Invasion site

(tail)
Magnification 


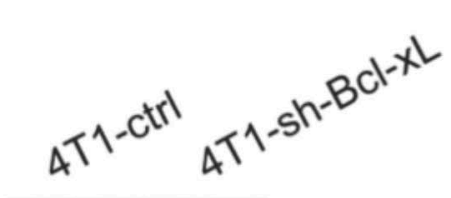

Vinculin

Bcl-xL
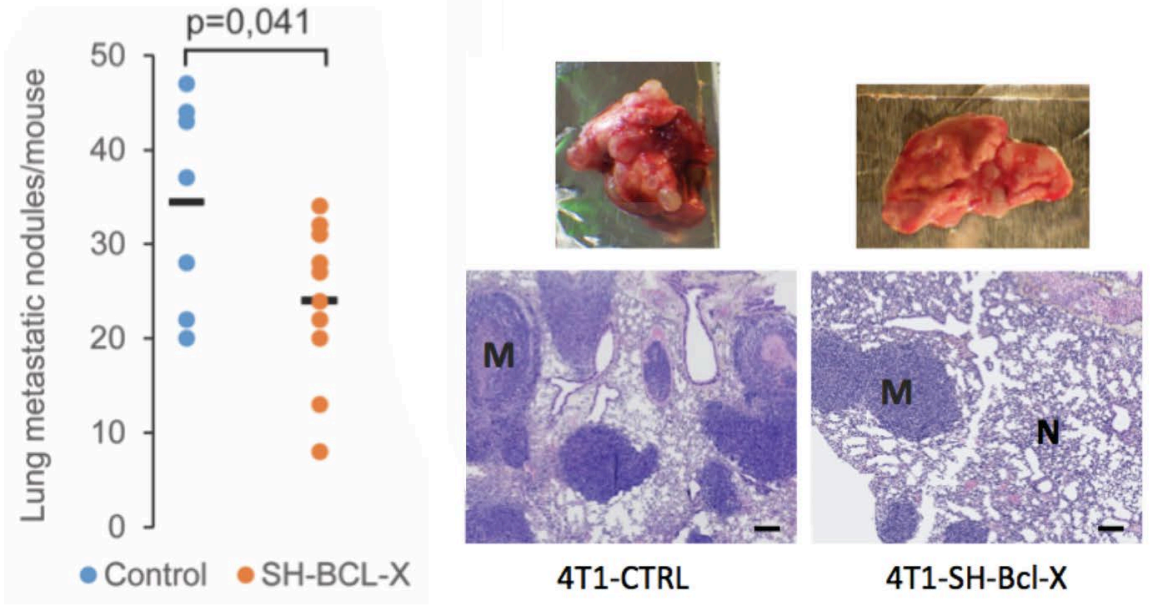


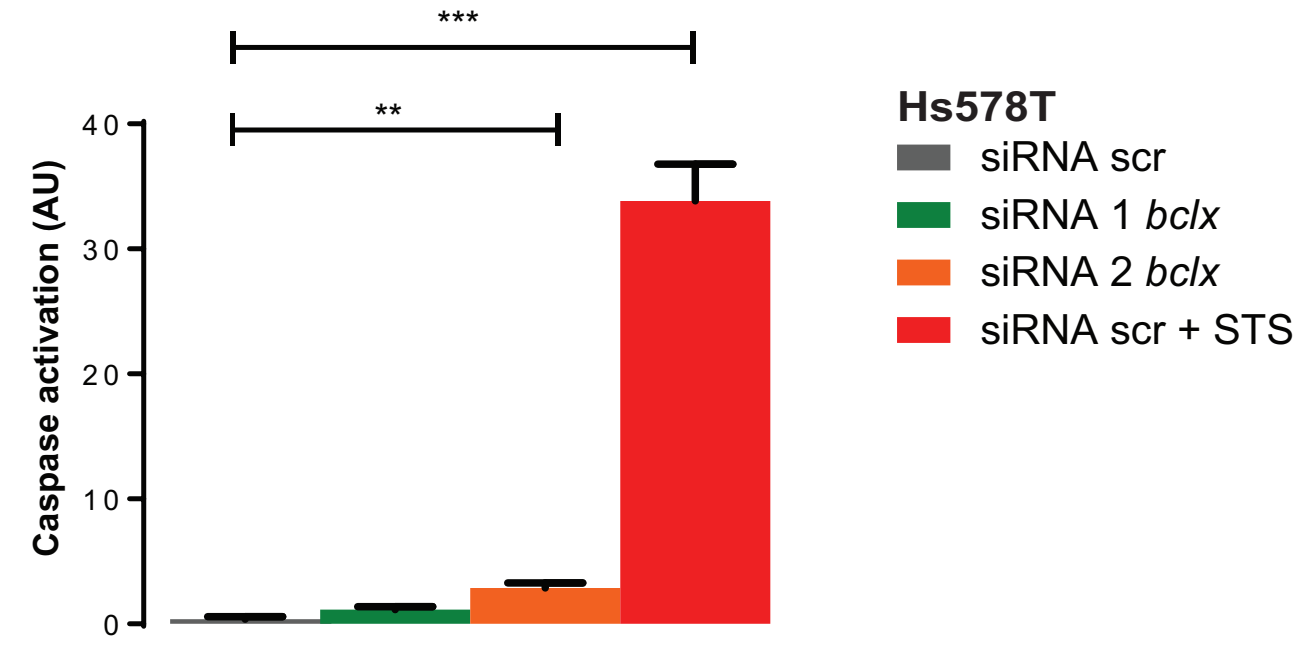

B

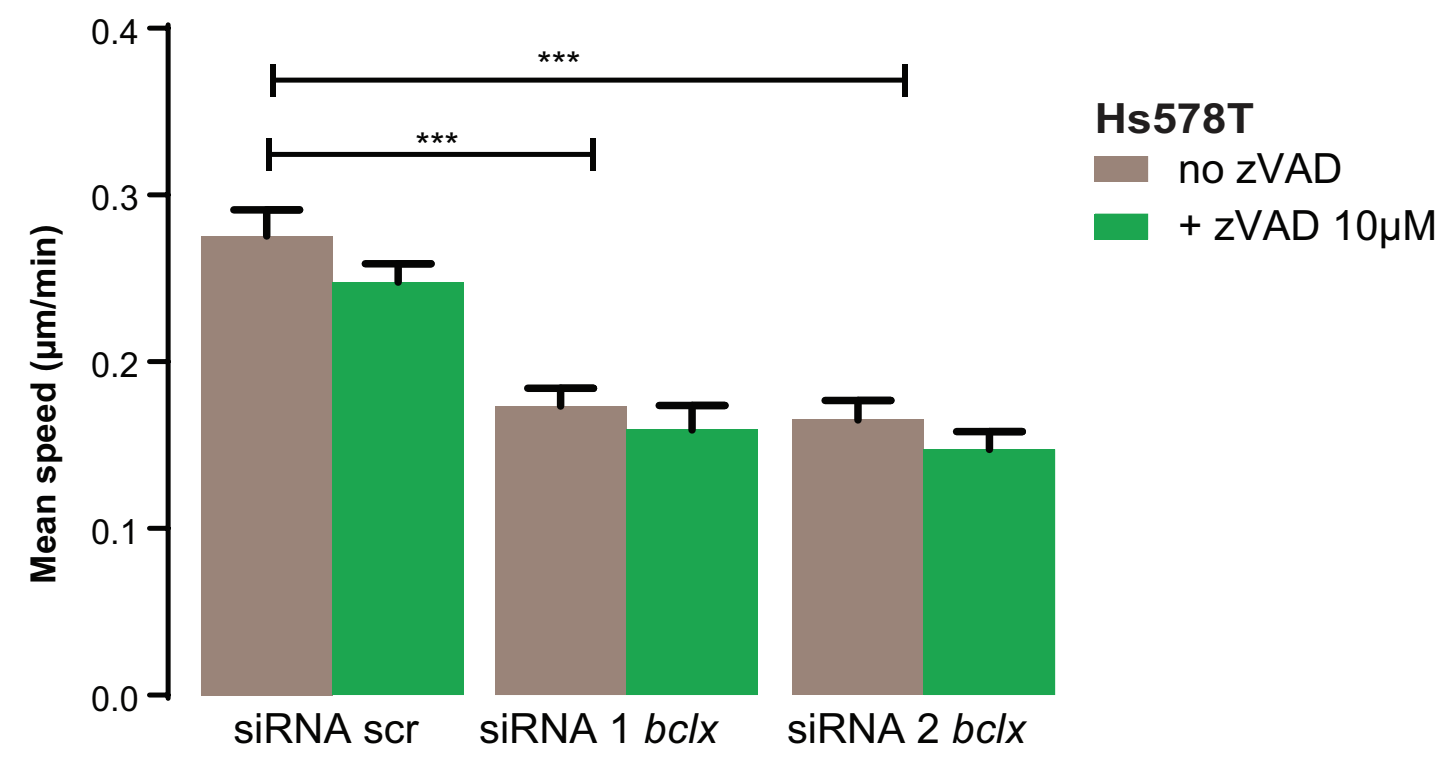

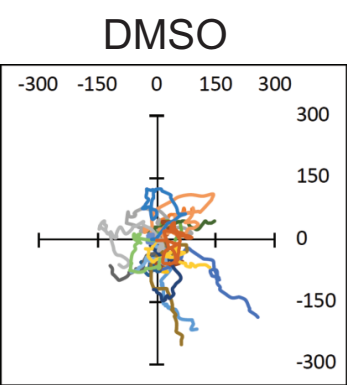

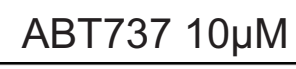

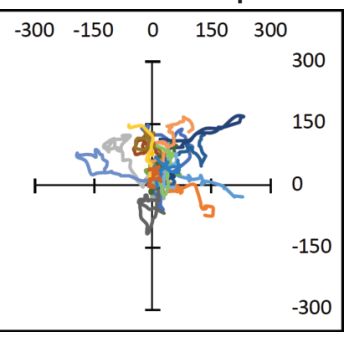

$-3$
$-30$

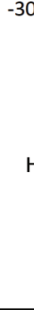

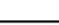

00

300

150

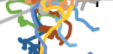

or

$-150$

$-300$

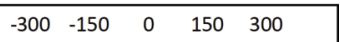

$\begin{array}{rrrr} & 0 & 150 & 300 \\ & & 300\end{array}$

150
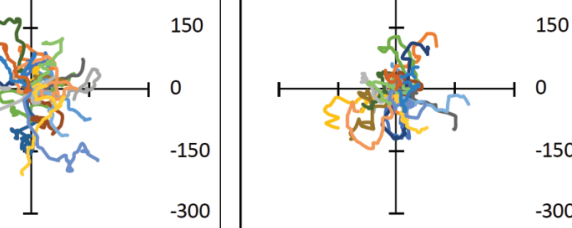

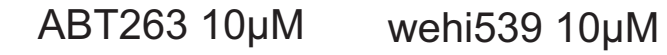

D

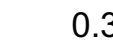

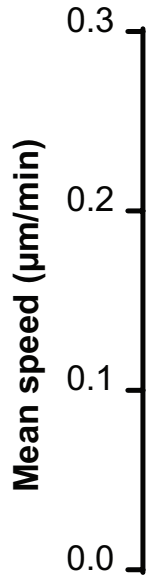

Hs578T

DMSO

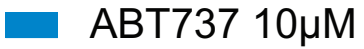

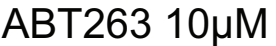
wehi $53910 \mu \mathrm{M}$ 
A
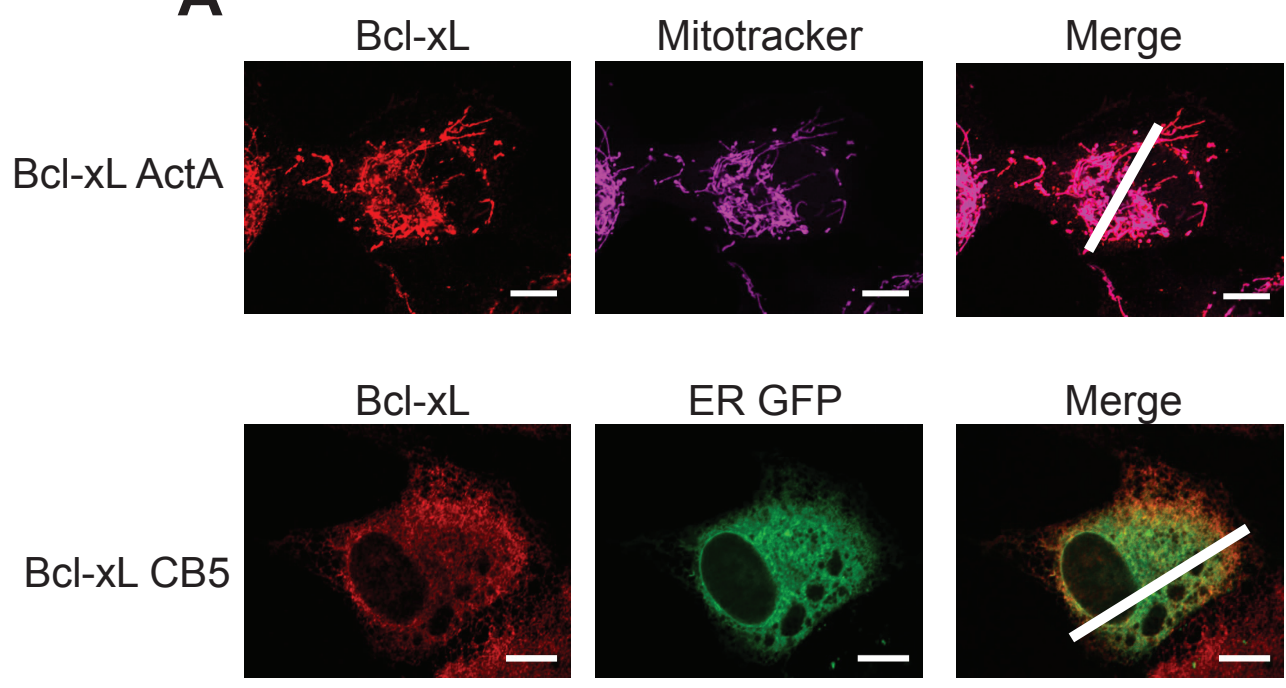

B
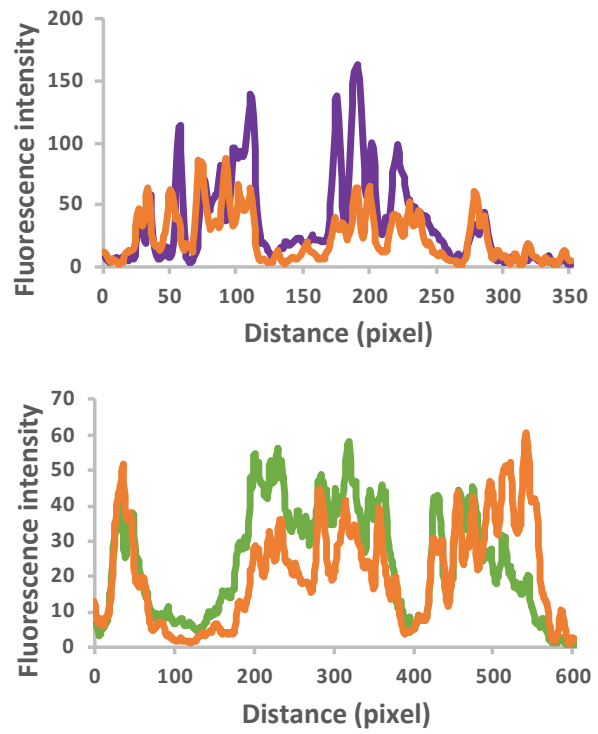

C

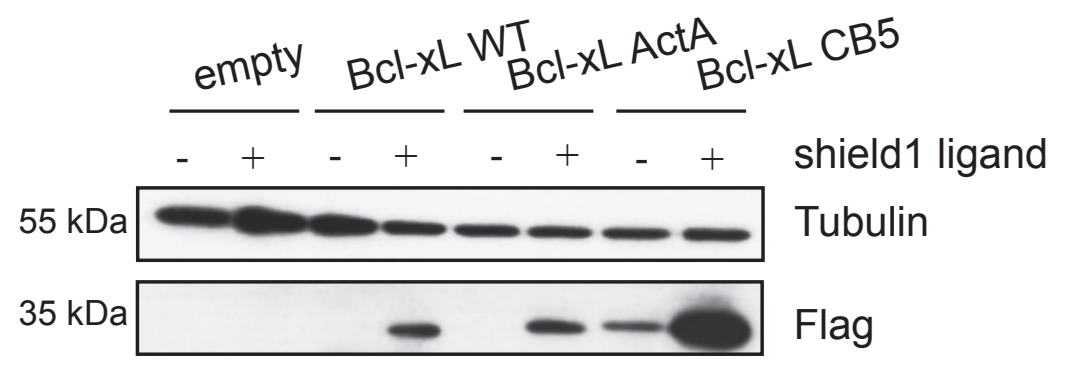

D

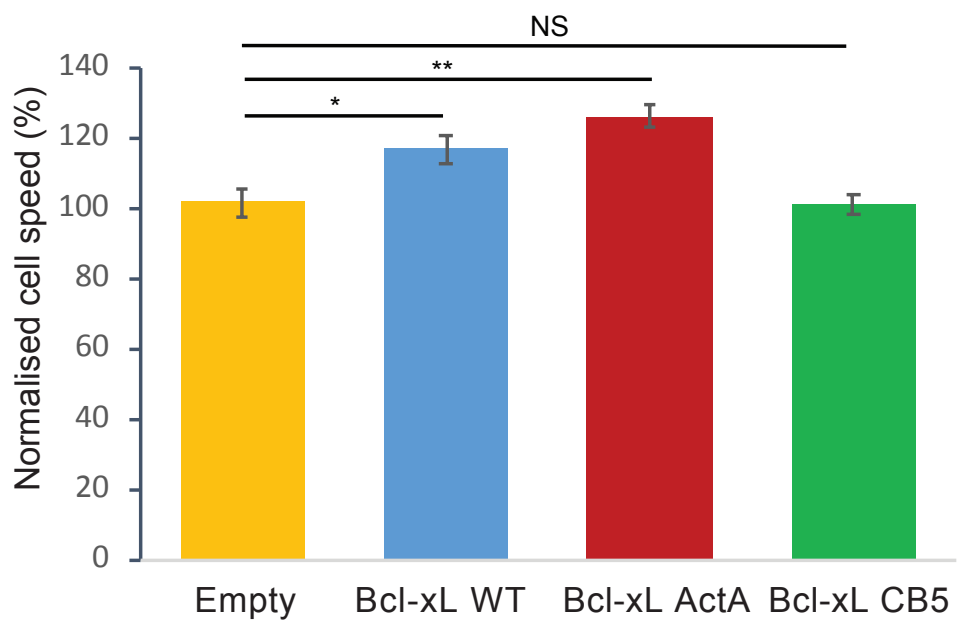

DD Flag Bcl-xL TM Bcl-xL WT

DD Flag Bcl-xL ActA Mitochondrial Bcl-xL DD Flag Bcl-xL CB5 ER- Bcl-xL proteasomal degradation

$\bigcirc 0$
+ ligand

protein stabilized 
A

\begin{tabular}{|c|c|}
\hline $\begin{array}{c}\text { Peptide } \\
\text { name }\end{array}$ & Sequence \\
\hline BH4 & TAT-MSQSNRELVVDFLSYKLSQKGYSW \\
\hline Scr & TAT-WYSKQRSLSGLVMYVLEDKNSQFS \\
\hline
\end{tabular}

B

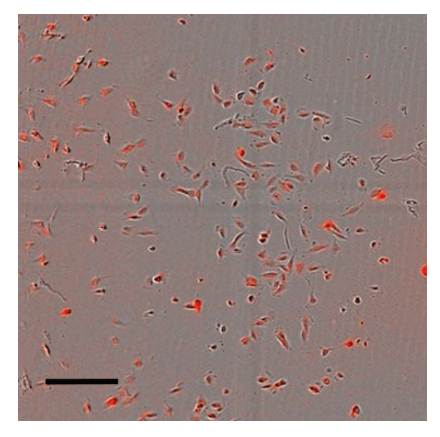

Hs578T + TAT scrBH4

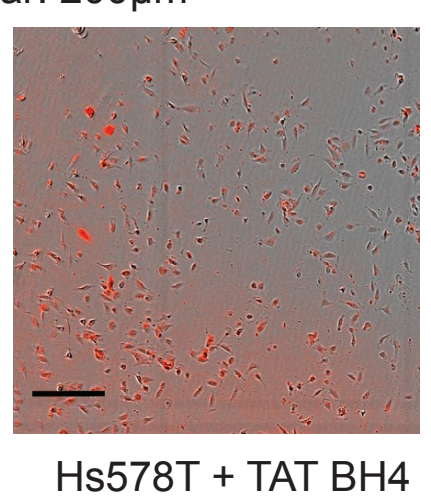

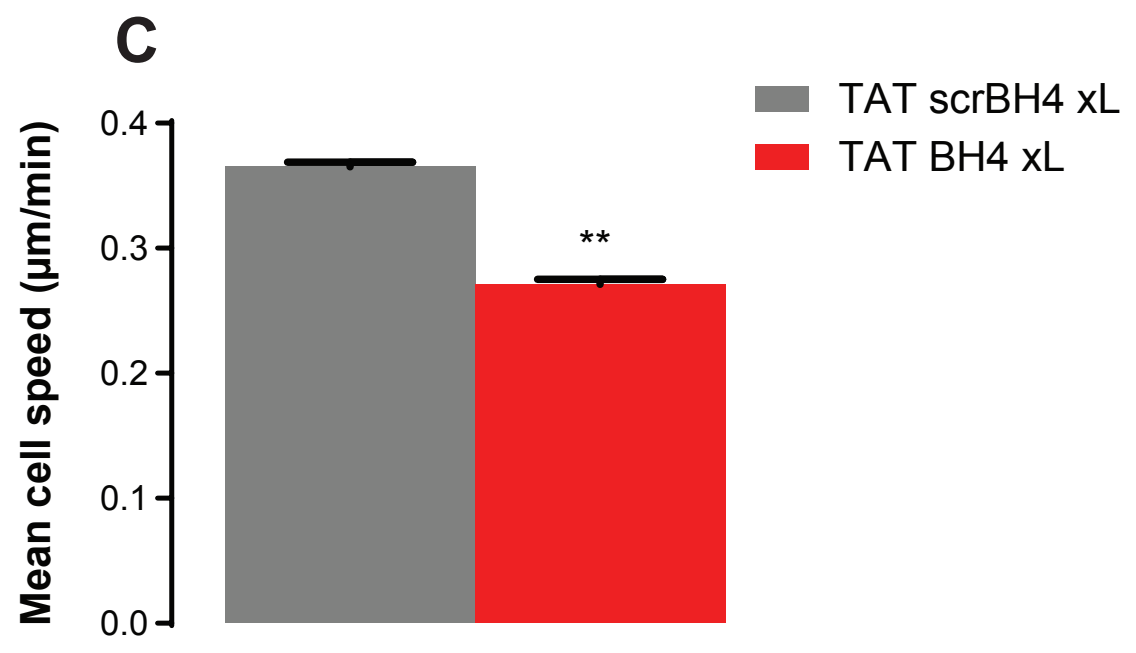


A

Oxygen Consumption Rate

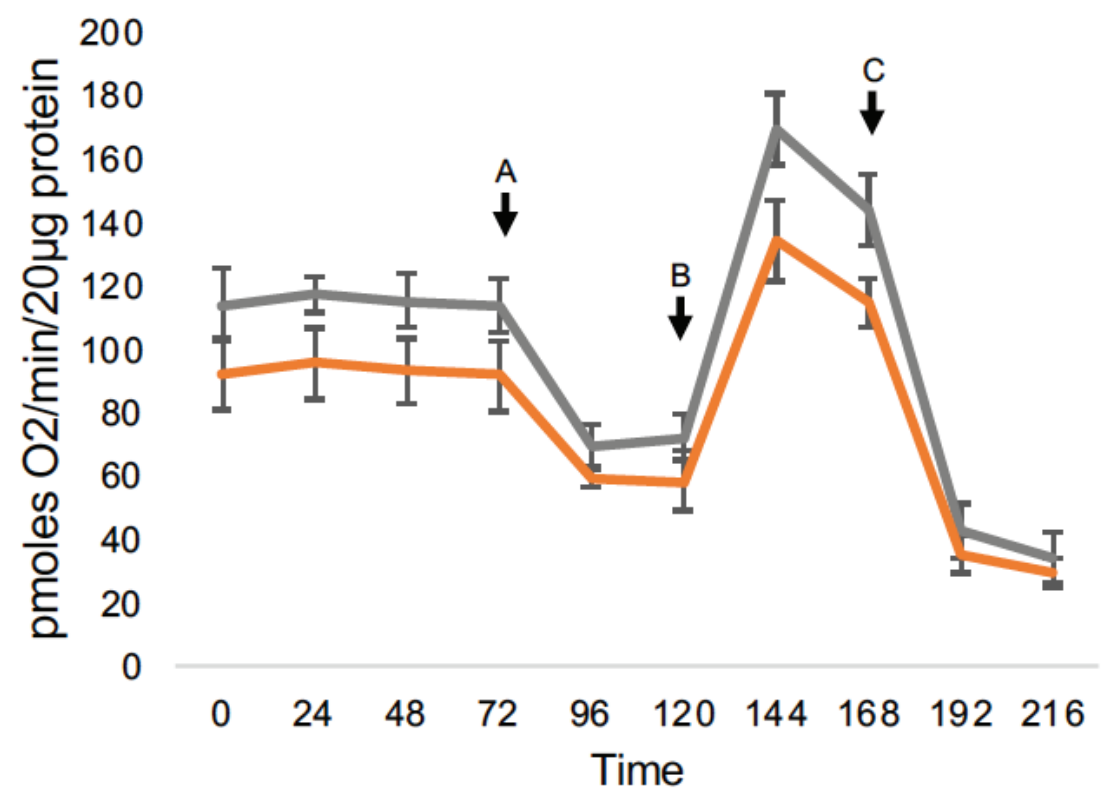

- Control $\longrightarrow$ bclx KO

C

Coupling efficiency

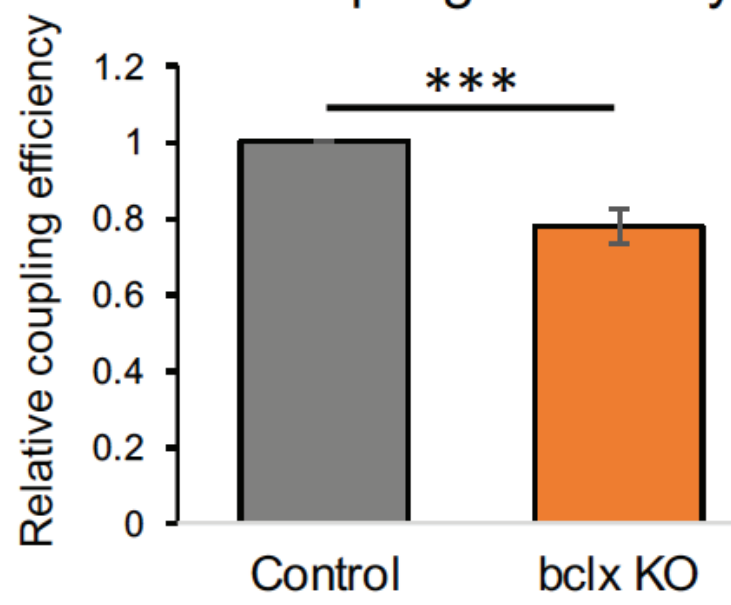

E

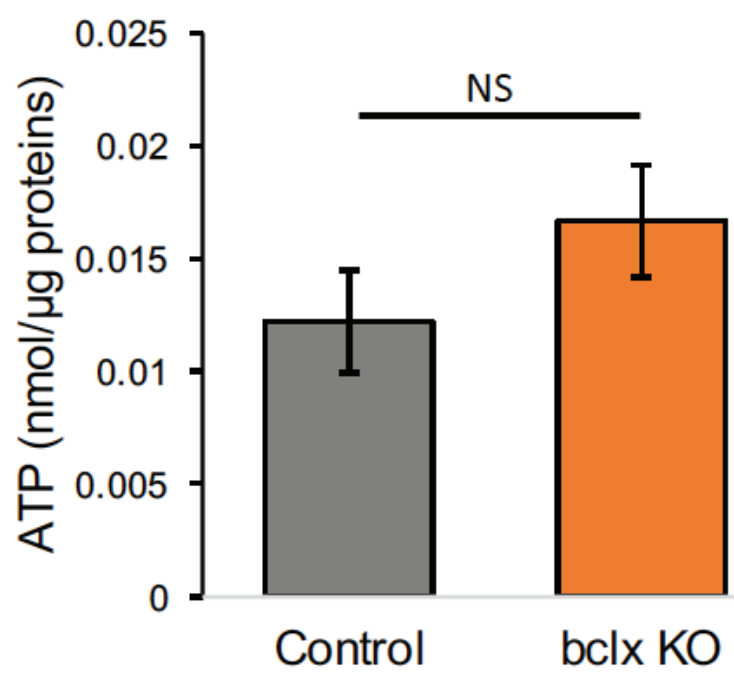

D

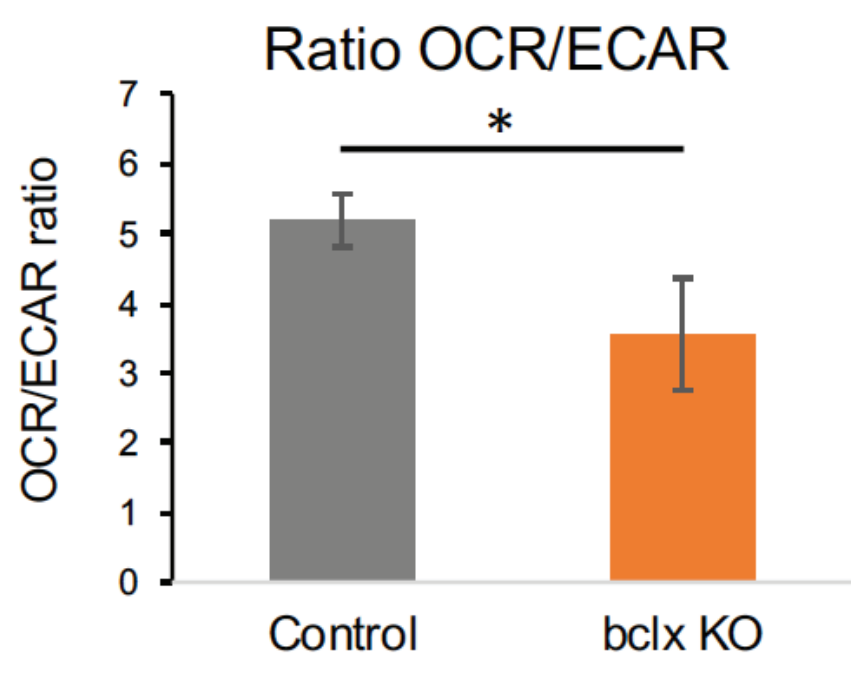

F

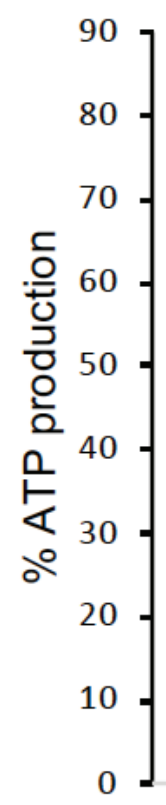

Control bclx KO

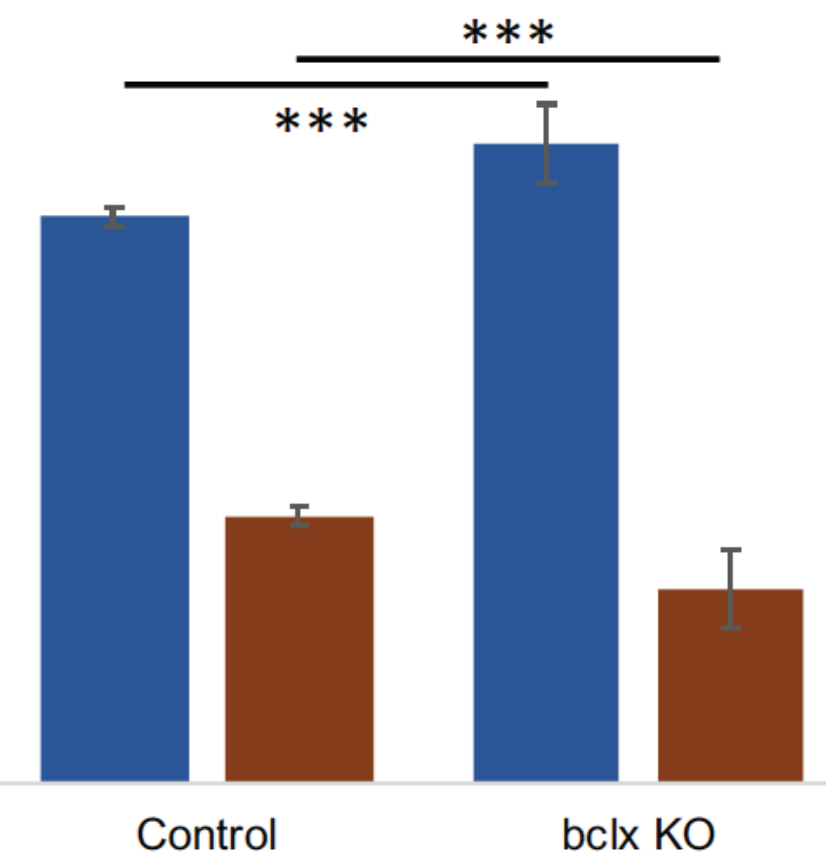

\section{Basal OCR}

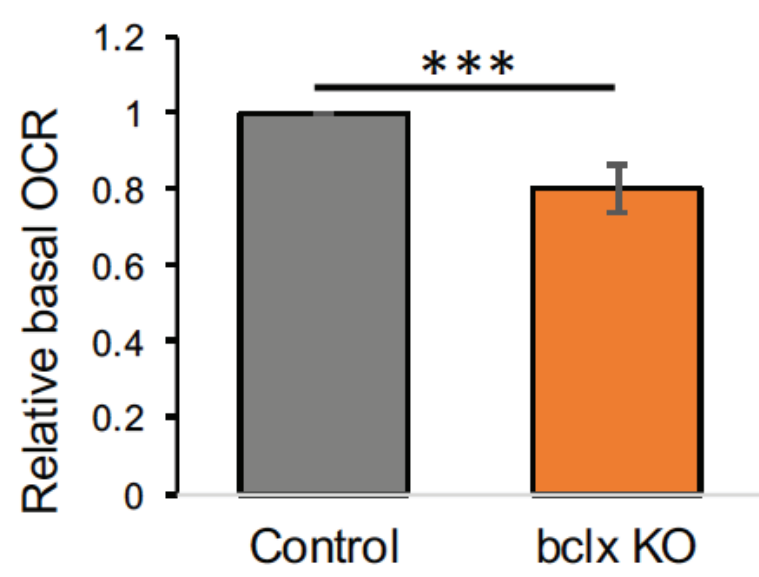

aTPglyc $\square$ ATPox 
A

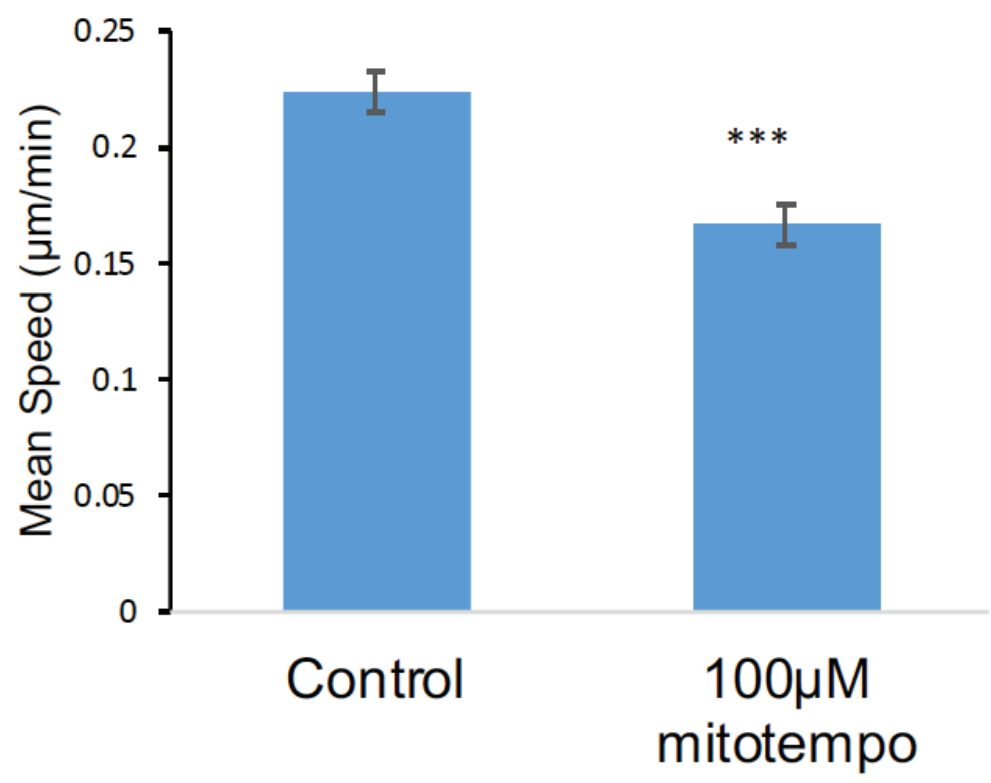

B

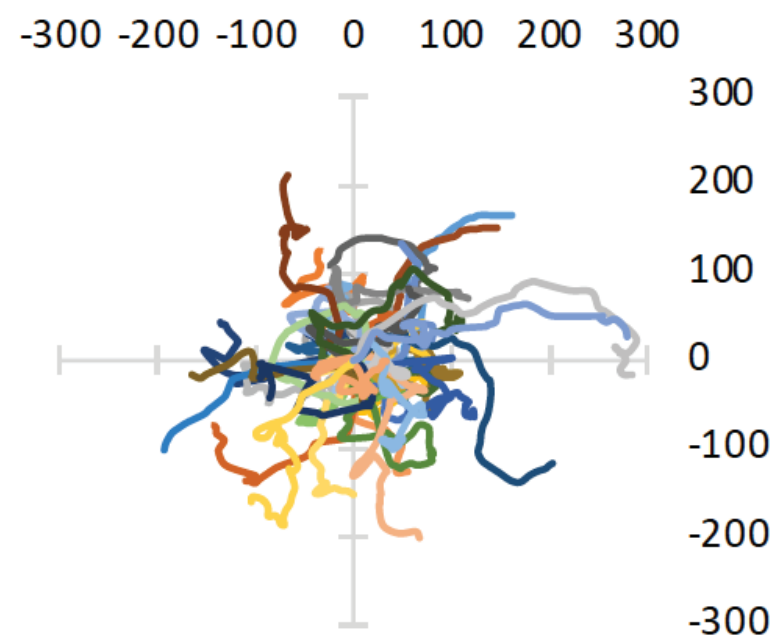

Control

C

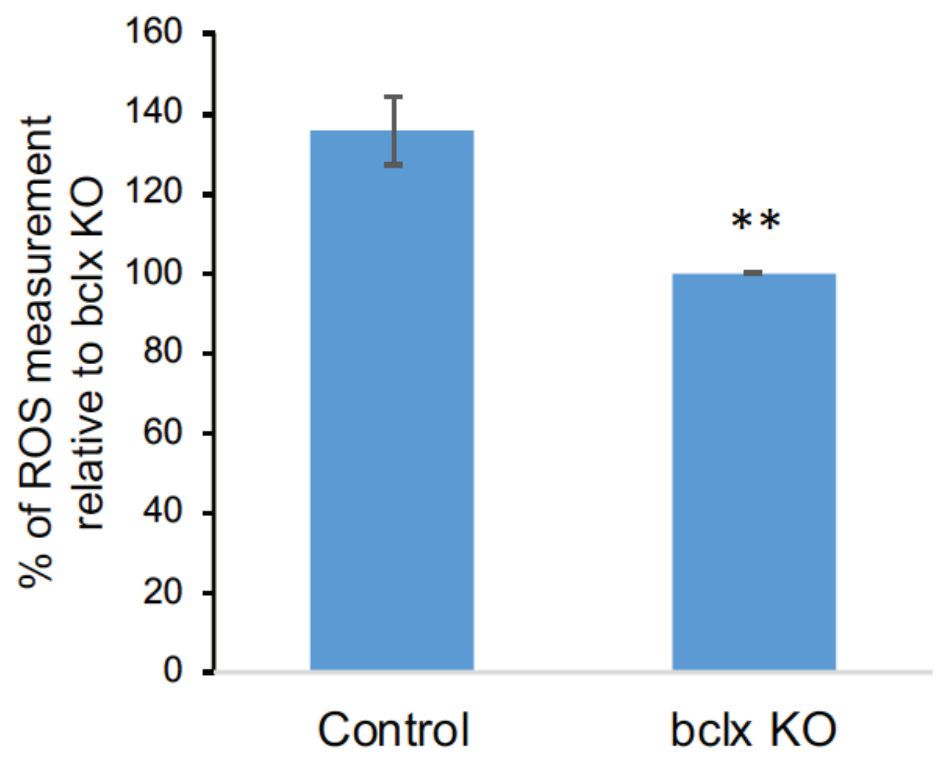

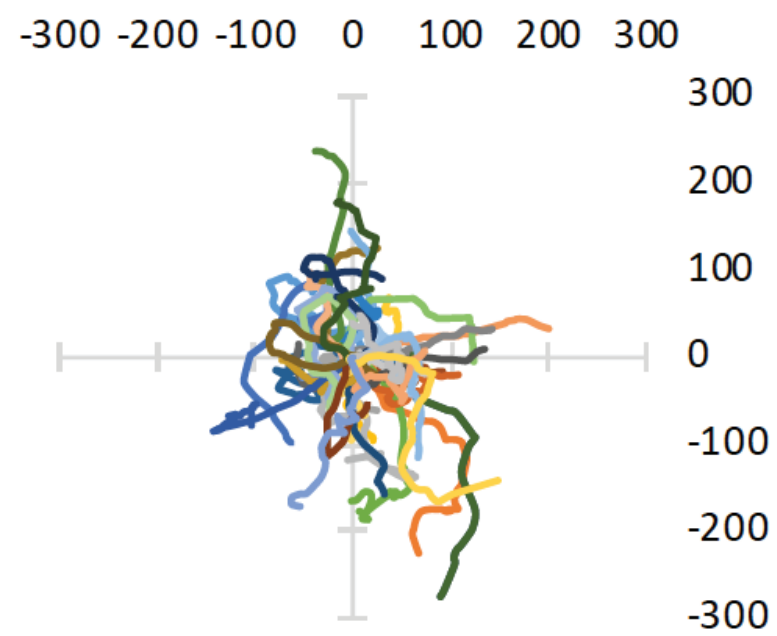

Mitotempo $100 \mu \mathrm{M}$
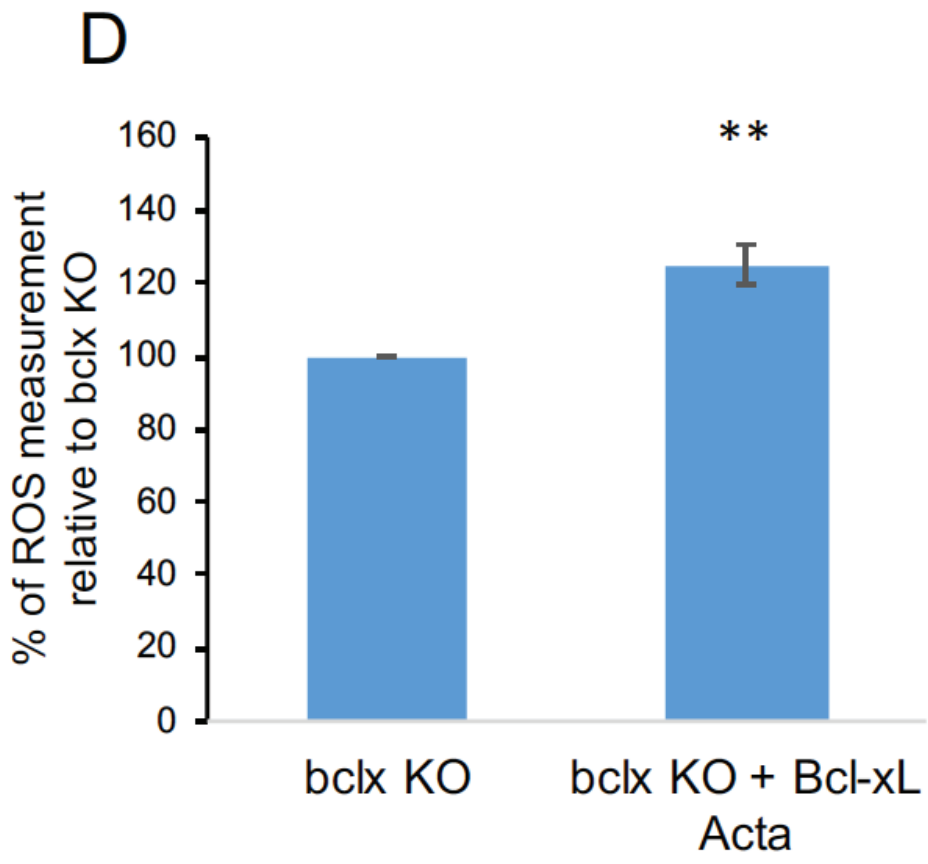


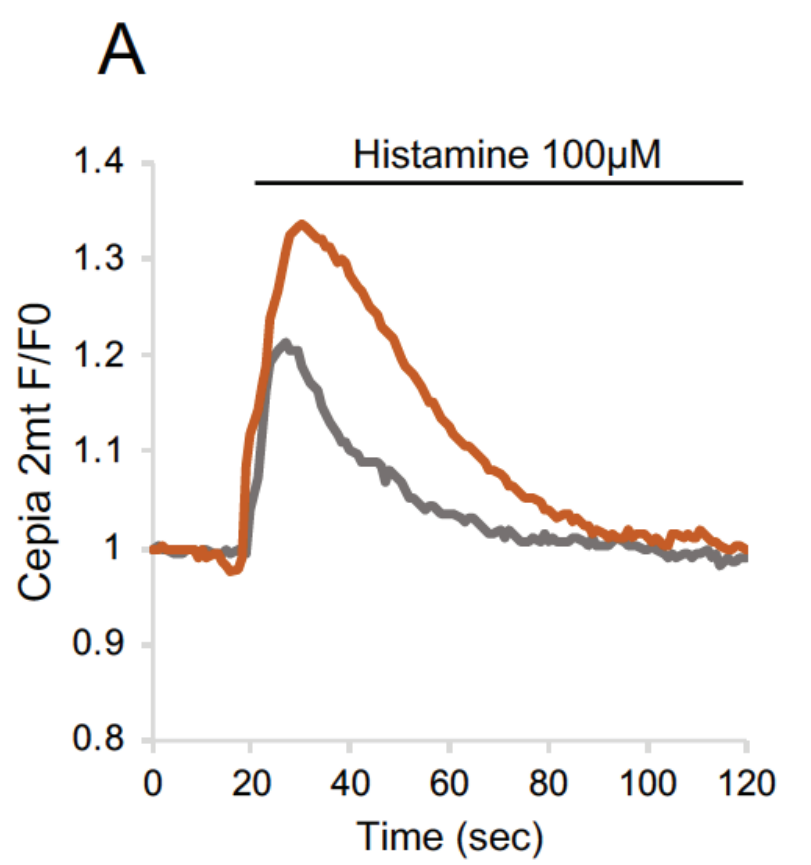

C

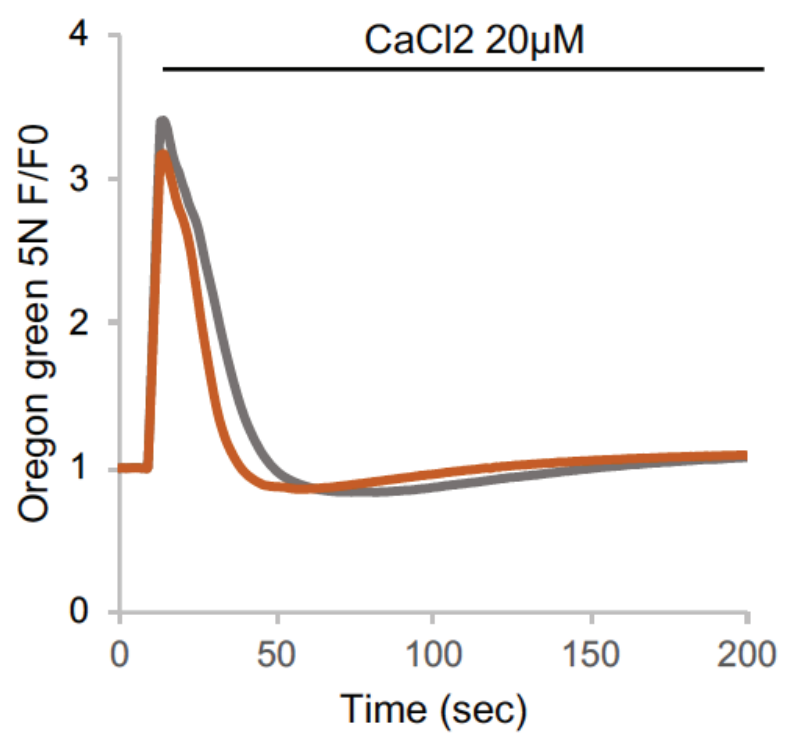

E

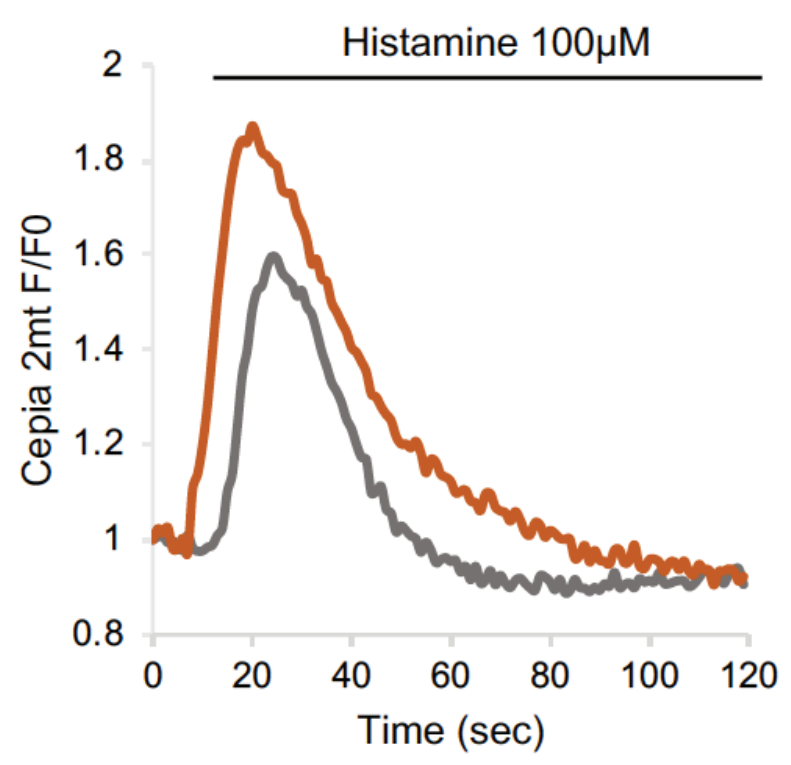

\section{B}
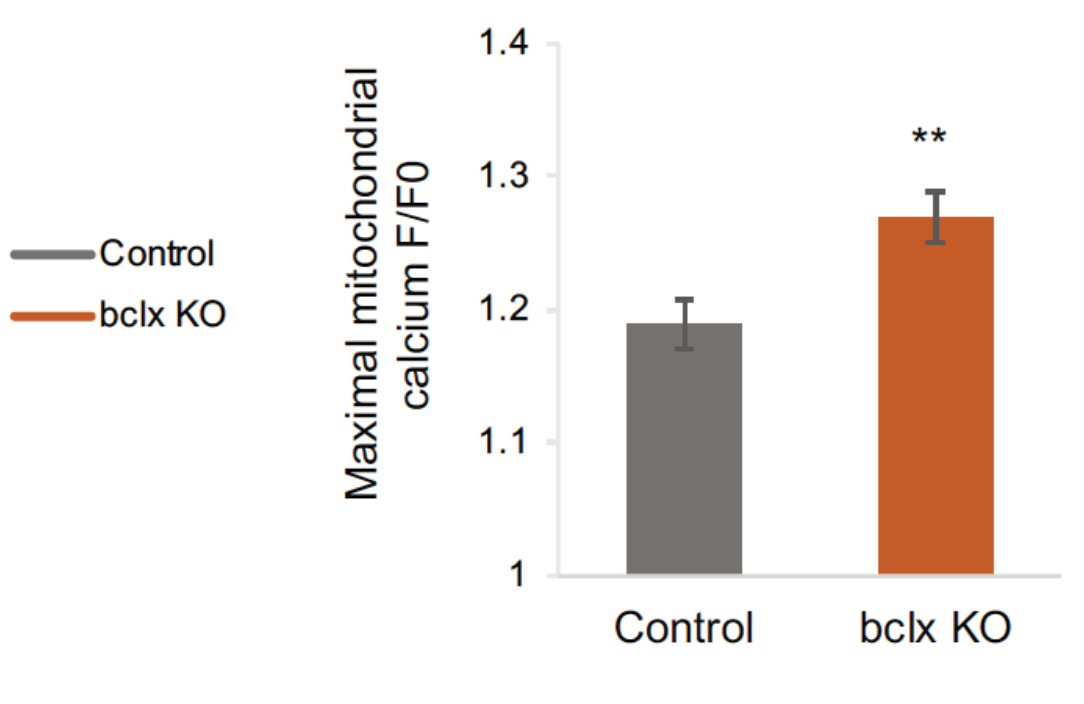

D

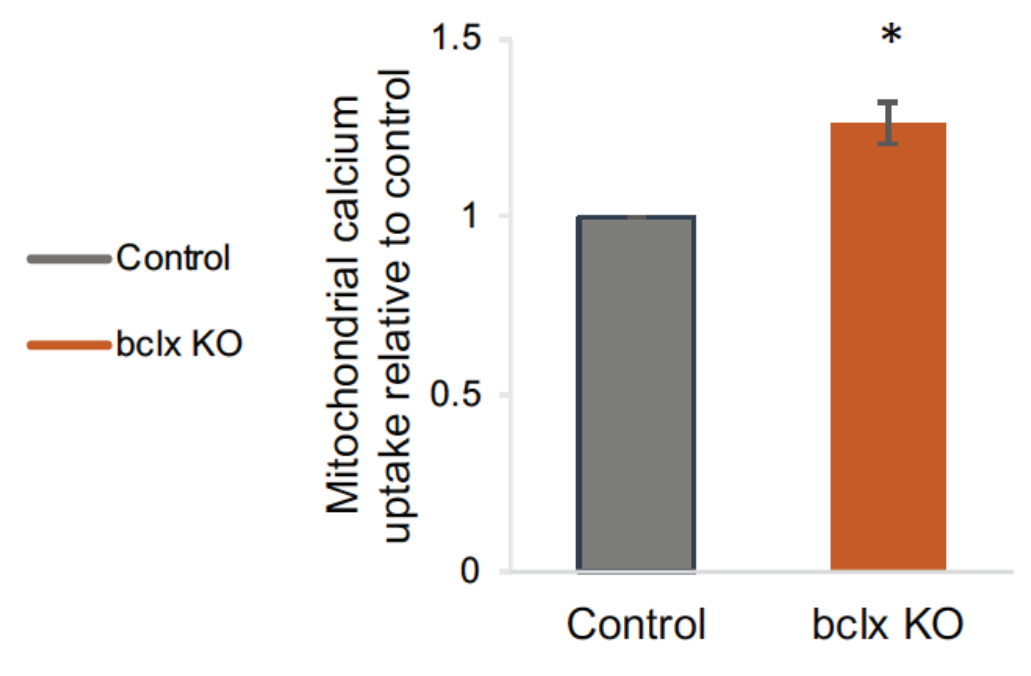

F

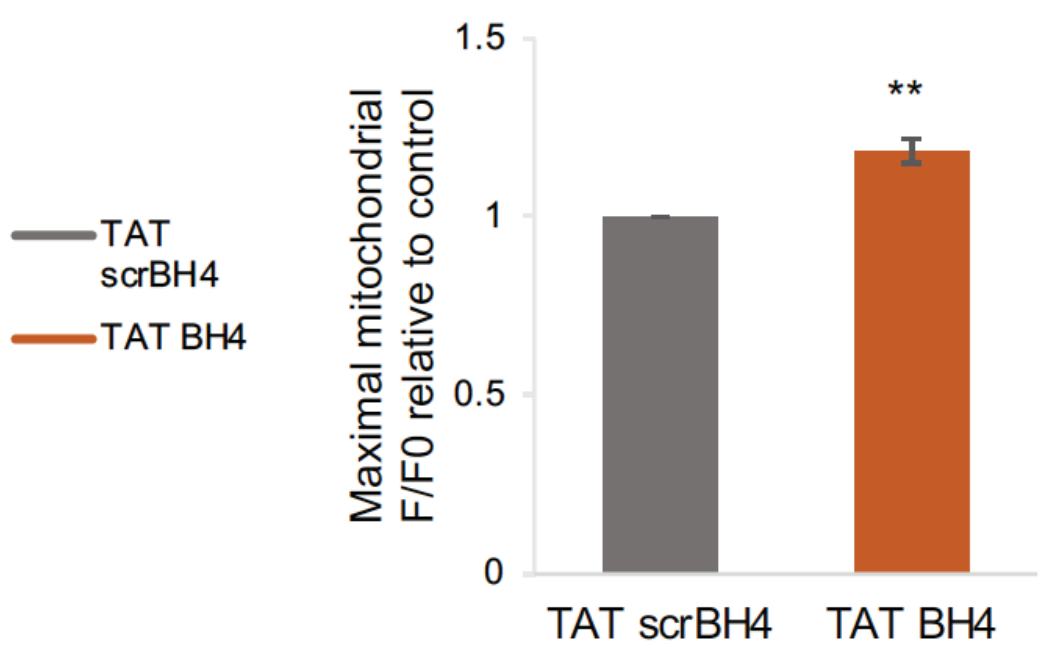

